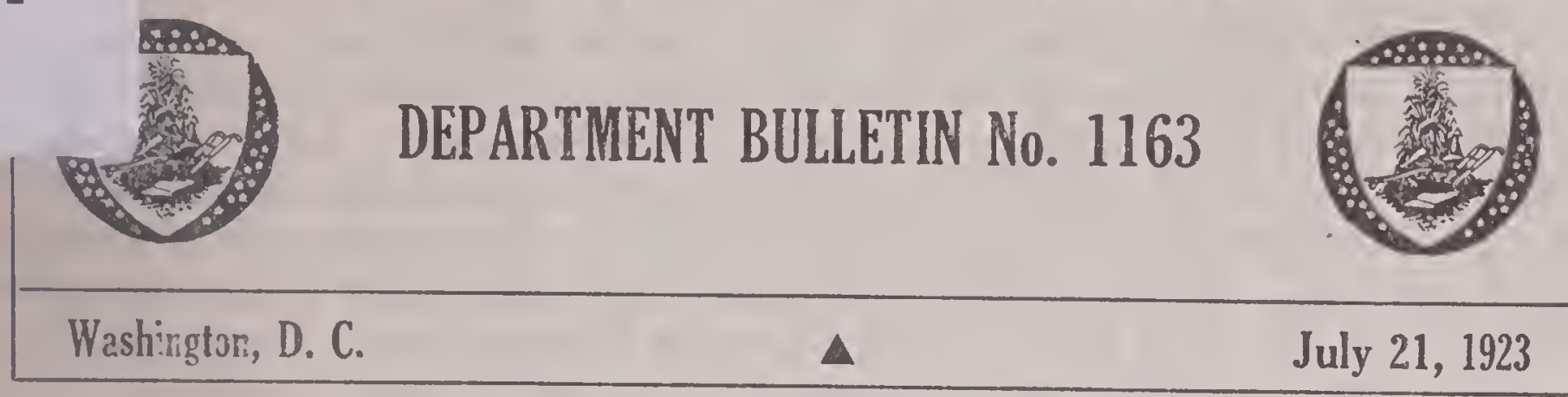

\title{
A STUDY OF DECAY IN DOUGLAS FIR IN THE PACIFIC NORTHWEST.
}

By J. S. Boyce, Pathologist, Office of Investigations in Forest Pathology, Bureau of Plant Industry.

\section{CONTENTS.}

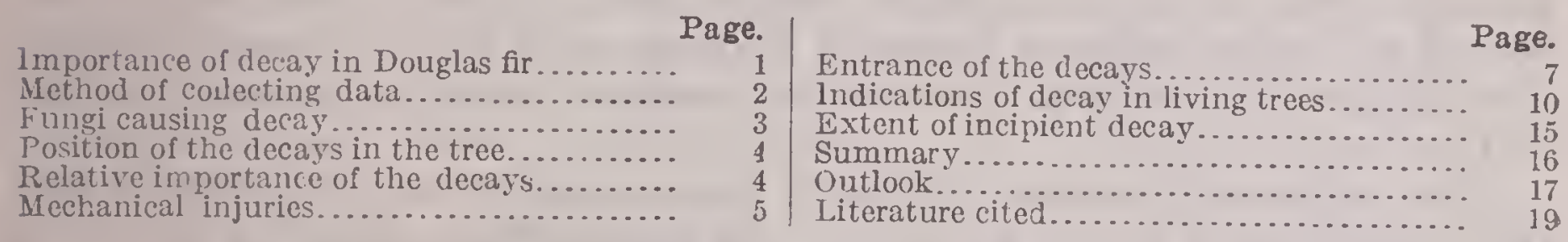

\section{IMPORTANCE OF DECAY IN DOUGLAS FIR.}

Douglas fir is the most important timber tree in the Pacific Northwest, covering, as it does, the greater part of the foothills and lower slopes of the Cascade Mountains and the Coast Range in practically pure stands of great density. The stand of this species in Oregon and Washington is estimated at 505 billion feet $(6, \mathrm{p} .23),{ }^{1}$ or nearly onefourth of the remaining merchantable timber in the United States.

The loss through decay in Douglas fir in this region is very high. While some overmature stands are relatively sound a loss of 20 per cent in such stands is not uncommon. In certain cases the cull figure may reach 50 per cent or more, so high that in timber on difficult. ground it becomes impossible to $\log$ at a profit. It is only in young stands of second growth that Douglas fir is uniformly sound. Plate I shows defective trees left uncut after logging in an overmature stand. In this instance about 25,000 feet board measure per acre was left standing. Where clear cutting is practiced numerous logs and entire trees remain on the ground after logging, absolutely worthless on account of decay. This is illustrated in Plate II. Practically all the large pieces were left because of rot.

Recognizing the importance of this question, foresters and lumbermen in the Douglas fir region have repeatedly felt the need for exact information on decay in Douglas fir. This bulletin presents observations by the writer and the results of a preliminary study. ${ }^{2}$

1 The serial numbers (italic) in parenthe e; rofe: to "Literature cited" at the end of this bulletin.

2 This study was made in the summer of 1917 under the cirection of Dr. E. P. Meinecke. 'To him the writer is indebted for supervision and assist ince throughout the course of the field work. The project was a cooperative one with the Forest Service of the United States Department of Agriculture, and acknowledgment is made to Forest Examiner F. B. Kellogg for his part in collecting the fielil data. much more detailed study of decay in Douglas fir is now in progress, but will not be completed for severa $\mathrm{I}$ years.

$42198-23-1$ 


\section{METHOD OF COLLECTING DATA.}

The trees selected for study were part of a defective, overmature stand of pure Douglas fir on the west slope of the Cascade Mountains at McCredie Hot Springs, above Oakridge, Lane County, Oreg. The area was at an elevation of about 2,000 feet above sea level, and the local topography was characterized by moderate slopes and almost level benches. The stand was quite typical of the bulk of the Douglas fir type on the west slope of the Cascade Mountains.

Each tree was felled with a stump height of $1 \frac{1}{2}$ feet measured at a point halfway on the slope. The bole was then cut into 16-foot logs to an 8-inch top-diameter limit inside the bark. Complete measurements were then taken. Next, the logs were split open and any further data available recorded. In this way it was possible to study each tree very completely, particularly with reference to the character and distribution of decay. Volumes of the trees were worked up in both board and cubic feet. The board-foot volume included the merchantable portion of each tree from the stump height of $1 \frac{1}{2}$ feet to a diameter limit of 8 inches inside bark. The 16-foot logs were scaled with the Scribner Decimal C scale and the volume of decay determined in accordance with the standard scaling practice of the Forest Service (5).

The cubic-foot volume included the contents of the entire stem from the ground level to the tip. In computing volumes the stump was considered as a cylinder, each 16-foot $\log$ as the frustum of a paraboloid, applying the Smalian formula (2, p. 161), the top (that is, the section from the 8-inch diameter inside bark to the tip) as a cone, and a broken section of the top which did not include the tip as the frustrum of a cone. The actual cubic-foot volume of decay was computed by the same formulas.

A general idea of the size and age of the trees analyzed is given in Table 1.

TABLE 1 -Size and age of Douglas fir trees studied.

\begin{tabular}{|c|c|c|c|c|c|}
\hline \multirow{2}{*}{ Age class. } & \multirow{2}{*}{$\begin{array}{c}\text { Average } \\
\text { age } \\
\text { (years). }\end{array}$} & \multirow{2}{*}{$\begin{array}{l}\text { A prage } \\
\text { dlameter } \\
\text { breast } \\
\text { high } \\
\text { (inches). }\end{array}$} & \multicolumn{2}{|c|}{$\begin{array}{l}\text { Pcrcentage of } \\
\text { total volume. }\end{array}$} & \multirow{2}{*}{$\begin{array}{l}\text { Number } \\
\text { of trees, } \\
\text { basis. }\end{array}$} \\
\hline & & & $\begin{array}{l}\text { Cubic } \\
\text { feet. }\end{array}$ & $\begin{array}{l}\text { Board } \\
\text { fect. }\end{array}$ & \\
\hline 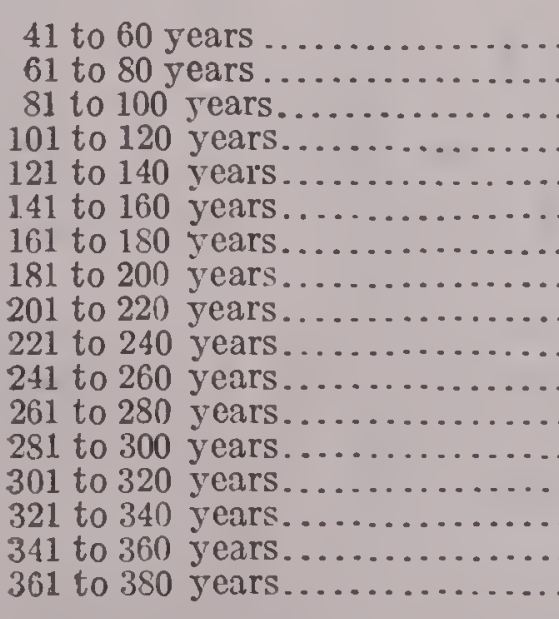 & \begin{tabular}{r}
59 \\
68 \\
95 \\
103 \\
129 \\
$\cdots$ \\
\hdashline 9. \\
195 \\
214 \\
230 \\
240 \\
271 \\
284 \\
309 \\
333 \\
348 \\
362 \\
\end{tabular} & \begin{tabular}{r}
9.5 \\
12.1 \\
14.0 \\
16.3 \\
16.0 \\
$\cdots \cdots .$. \\
\hdashline 13.7 \\
25.3 \\
27.5 \\
27.9 \\
28.1 \\
29.2 \\
29.7 \\
29.8 \\
28.9 \\
39.6
\end{tabular} & $\begin{array}{r}0.04 \\
.91 \\
.53 \\
.75 \\
.15 \\
\ldots . \\
1.36 \\
15.49 \\
32.69 \\
10.81 \\
15.81 \\
1.52 \\
6.07 \\
10.38 \\
2.48 \\
1.00\end{array}$ & $\begin{array}{r}0 \\
0.62 \\
.42 \\
.62 \\
.11 \\
\ldots . . \\
\cdots .11 \\
1.11 \\
33.99 \\
11.20 \\
15.74 \\
1.63 \\
5.97 \\
10.22 \\
2.46 \\
1.10\end{array}$ & $\begin{array}{r}1 \\
8 \\
3 \\
3 \\
1 \\
\text { (1) } \\
0 \\
5 \\
29 \\
47 \\
15 \\
25 \\
2 \\
9 \\
16 \\
4 \\
1\end{array}$ \\
\hline Combined.... & 238 & 26.1 & & & 1 ti9 \\
\hline
\end{tabular}

1 One tree, too small to consider. 
The trees studied were not clear cut from a given area, but average trees both sound and decayed were selected to obtain preliminary information on which an extensive study of decay in Douglas fir could be based. This will be brought out as the discussion proceeds.

In all 170 trees were felled, bucked up, split open, and studied. One of these was only 2 inches in diameter breast high, so it was dropped from consideration, leaving 169 trees with a total volume of 203,920 feet board measure and 33,703.12 cubic feet.

\section{FUNGI CAUSING DECAY.}

Four species of fungi are responsible for all but an infinitesimal portion of the decay in Douglas fir. They are the ring-scale fungus (Trametes pini (Thore) Fr.), the velvet-top fungus (Polyporus schweinitzii Fr.), the quinine fungus (Fomes laricis (Jacq.) Murr.), and the rose-colored Fomes (Fomes roseus (Alb. and Schw.) Cke.). The decays caused by these four wood-destroying fungi in living trees are confined to the heartwood.

The ring-scale fungus causes decay commonly known as conk-rot in this region (ring-scale or red-rot in the pine regions), in which the wood is riddled with small white pits or cavities, apparently separated by sound wood. This is shown in Plate III, Figure 1. In its incipient stages, before the appearance of the white pits, the decay appears as a pronounced reddish purple or olive-purple discoloration, often bounded by a narrow zone of pronounced red color. The sporophores, or conks, are very common in overmature Douglas fir stands. These fruiting bodies issue from the tree through knots and are perennial. They vary in size and in shape from bracketlike to hoof shaped. The upper side is a dull grayish or brownish black, rough, and with concentric furrows parallel to the light-brown margin. The under side is a grayish brown or rich brown color with large irregular pores. The substance or context of the sporophores is corky or punky. Plate IV shows the appearance of the sporophores on a living tree.

The velvet-top fungus causes a red-brown friable rot in the final stage. The incipient decay is very difficult to detect. It first becomes noticeable as a faint yellowing or browning of the normal heartwood, which still seems to be firm and hard but in reality is seriously weakened. 'The sporophores, or conks, of this wood destroyer appear either on the infected tree or on the ground near by and are annual. They are rather large, with a light-brown upper surface, an olive or dirty green under surface, and have a cheesy consistency when young, but when old and dry are a dark rusty brown and corky. Sporophores on the ground have a short thick stalk. Plate V, Figures 1 and 2, illustrate both sporophores and decay of this fungus.

The quinine fungus has a large, conspicuous, whitish perennial sporophore, not at all common on living trees. The substance of the sporophore is white, soft, and cheesy when young and rather crumbly and chalky when old and dry, with an exceedingly bitter taste. Hence the name. On the older sporophores the upper surface is rough and chalky white and brownish in color. The pores are small and regular. Plate VI, Figure 1, shows a sporophore. 'The typical decay is a crumbly brown rot easily recognizable by its mycelium felts or sheets (i. e., closely woven masses of fungus hyphæ). This characteristic is brought out in Plate VI, Figure 2. The incipient decay which appears as a faint brownish discoloration is not easy to recognize. 
The sporophores of the rose-colored Fomes are easily recognized by the delicate rose color of the under surface. The pores are small. The upper surface is rough, hard, and black. This is illustrated in Plate III, Figure 2. The decay caused by this organism is a yellowbrown crumbly rot, with mycelium felts much less conspicuous than those of the quinine fungus. The incipient decay is indicated by a faint brownish color, the outer limit of which is sometimes marked by a zone of brownish green discoloration.

\section{POSITION OF THE DECAYS IN THE TREE.}

The decay caused by the ring-scale fungus and that caused by the quinine fungus are not confined to any one portion of the bole but commonly extend throughout the tree.

On the other hand, the decay caused by the velvet-top fungus is a typical butt-rot. Of the 70 infections of this decay in 68 trees, each separate focus of the rot in a tree being considered an infection, 94.3 per cent, or all but 4 , were in the stump or butt log. The decay usually does not extend higher than the first 16 -foot log. In 10 trees only did the decay go beyond the butt log, and the greatest upward extent in any one case was 37.4 feet above ground level. The average for all the butt infections was 10.41 feet above the ground. The measurements given include the incipient decay.

The decay caused by the rose-colored Fomes is usually confined to the upper portion of the tree in connection with dead tops, and often the rot does not extend into the merchantable portion of the infected tree. In all, there were 46 infections of this rot, and all but 9 of these were in the upper bole. Of those in the upper bole, 18, or almost 50 per cent, were in the top beyond the 8-inch diameter limit and caused no loss in merchantable volume.

For the sake of brevity in the remainder of this paper, the decays caused by these four fungi will be designated as follows:

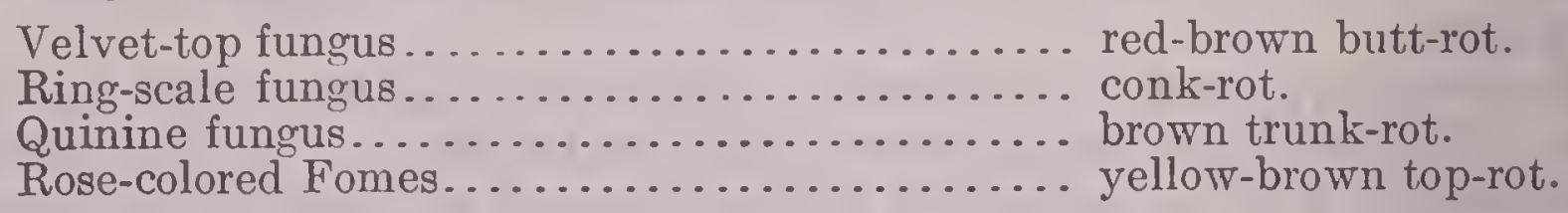

When used in tables the designations will be simply butt-rot, conkrot, trunk-rot, and top-rot.

\section{RELATIVE IMPORTANCE OF THE DECAYS.}

Conk-rot is responsible for by far the greatest amount of cull in Douglas fir. In fact, if the species was free from this defect it would take its place with the pines as a sound tree. This is brought out in Table 2.

In considering Table 2 it must be remembered that it is not based on trees clear cut from a given area. Consequently the figures on the percentage of infected trees and rolume of decay are not indicative of the actual loss through decay in stands of Douglas fir, but they do indicate the relation of the various decays. Under "unknown rots" are placed a number of small infections of decays whose cause could not be determined and one infection caused by Ganoderma oregonense Murr., which resulted in a slight loss.

Conk-rot stands out as the all-important cause of decay. The volume destroyed by this decay in comparison with the others is far 
greater than the ratio of infected trees would indicate. For example, only about one-third more trees are infected with conk-rot than with red-brown butt-rot, yet the board-foot volume of decay is slightly more than 18 times as great. Conk-rot is usually quite extensive in an infected tree, particularly in the mechantable portion of the bole.

TABLE 2.-Relative importance of the different kinds of decay in Douglas fir.

\begin{tabular}{|c|c|c|c|c|c|c|c|}
\hline \multirow{3}{*}{ Kinds of decay. } & \multirow{2}{*}{\multicolumn{2}{|c|}{$\begin{array}{l}\text { Volume of decay, } \\
\text { percentage of gross } \\
\text { volume. }\end{array}$}} & \multirow{3}{*}{$\begin{array}{l}\text { Infected } \\
\text { trees, } \\
\text { percent- } \\
\text { age of } \\
\text { total. }\end{array}$} & \multicolumn{4}{|c|}{ Infections. } \\
\hline & & & & \multirow{2}{*}{$\begin{array}{c}\text { Number } \\
\text { basis. }\end{array}$} & \multirow{2}{*}{$\begin{array}{l}\text { Percent- } \\
\text { age of } \\
\text { total. }\end{array}$} & \multicolumn{2}{|c|}{ Average volume. } \\
\hline & $\begin{array}{l}\text { Board } \\
\text { fect. }\end{array}$ & $\begin{array}{c}\text { Cubic } \\
\text { feet. }\end{array}$ & & & & $\begin{array}{c}\text { Board } \\
\text { feer. }\end{array}$ & $\begin{array}{l}\text { Cubic } \\
\text { feet. }\end{array}$ \\
\hline 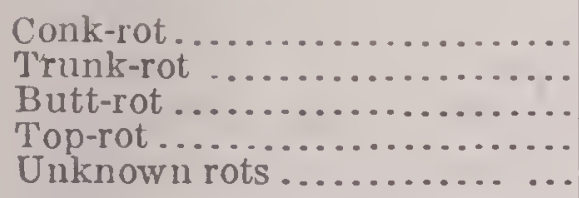 & $\begin{array}{r}38.4 \\
2.7 \\
2.1 \\
1.6 \\
.1\end{array}$ & $\begin{array}{r}22.5 \\
1.3 \\
1.2 \\
1.0 \\
.1\end{array}$ & $\begin{array}{r}61.0 \\
5.9 \\
40.2 \\
22.5 \\
18.9\end{array}$ & $\begin{array}{r}118 \\
15 \\
70 \\
46 \\
35\end{array}$ & $\begin{array}{r}41.6 \\
5.3 \\
24.6 \\
16.2 \\
12.3\end{array}$ & $\begin{array}{r}663 \\
369 \\
62 \\
72 \\
4\end{array}$ & $\begin{array}{r}64.2 \\
28.7 \\
5.9 \\
7.0 \\
1.0\end{array}$ \\
\hline Combined .............. & 44.9 & 26.1 & 87.6 & 284 & & 323 & 30.9 \\
\hline
\end{tabular}

While only a few trees showed brown trunk-rot in comparison to those with red-brown butt-rot and yellow-brown top-rot, yet the rolume of brown trunk-rot is greater than either of the others, particularly in board feet. This is due to the fact that brown trunkrot when it does occur is quite likely to cause the loss of all or most of the merchantable portion of the affected tree. Yellow-brown toprot and red-brown butt-rot, being localized, result in much less loss per tree, but make up for this in the many more trees with these decays. The greater loss through brown trunk-rot in board feet as compared to cubic feet in relation to red-brown butt-rot and yellowbrown top-rot is understood when it is remembered that the former is usually in the merchantable portion of the tree, while the latter two are often in the stump and top, which are not included in the board-foot volume but are figured in computing the cubic-foot volume.

Furthermore, red-brown butt-rot is of more importance than the figures would indicate, since seriously affected trees are quite subject to windfall, breaking off near the ground. Then, too, this decay destroys the valuable heartwood of the butt logs.

Of the total of 169 trees, 21 were free from decay, while in the remaining 148 there were 284 infections, or an average of 1.9 infections per infected tree. Some trees had as many as 6 individual infections. Again, in considering the infections conk-rot stands out both in the number of infections and particularly in the average volume of decay per infection. Trunk-rot has a high average volume of decay per infection, which shows again that this rot is of minor importance only because of the limited number of infections, but when a tree is once attacked destructive and extensive decay usually results.

\section{MECHANICAL INJURIES.}

Mechanical injuries on trees are of importance in that besides sometimes reducing the annual increment or causing an actual loss in merchantable volume from the mere presence of the injury they afford access to the heartwood of the tree for the spores of wooddestroying fungi. 
Wounds in Douglas fir, though quite common, are mostly superficial and heal rather rapidly. Rapid healing is particularly the case in younger trees. Wounds as a rule callus very irregularly, and as a result it is usually difficult or impossible to determine the exact dates when scars were made and callused over by counting the annual rings. In this respect Douglas fir differs strikingly from the clearcut, regular calluses characteristic of incense cedar and white fir. Furthermore, injuries in Douglas fir frequently result in the formation of prominent burls.

Of the trees studied, only 11 were entirely free from scars. The remaining 158 trees had 508 scars, open and healed over, an average of 3.2 wounds per tree. Table 3 shows the relative frequency of the various types of scars

TABLE 3.-Scars in Douglas fir.

\begin{tabular}{|c|c|c|c|c|c|c|c|c|c|}
\hline \multirow{2}{*}{ Type of scar. } & \multicolumn{3}{|c|}{ Number of scars, basis. } & \multirow{2}{*}{$\begin{array}{l}\text { Per- } \\
\text { cent- } \\
\text { age of } \\
\text { total } \\
\text { scars. }\end{array}$} & \multirow{2}{*}{ Type of scar. } & \multicolumn{3}{|c|}{ Number of scars, basis. } & \multirow{2}{*}{$\begin{array}{l}\text { Per- } \\
\text { cent- } \\
\text { age of } \\
\text { total } \\
\text { scars. }\end{array}$} \\
\hline & Open. & $\begin{array}{c}\text { Healed } \\
\text { over. }\end{array}$ & Total. & & & Open. & $\begin{array}{c}\text { Healed } \\
\text { over. }\end{array}$ & Total. & \\
\hline \multirow{2}{*}{$\begin{array}{l}\text { Fire scars ......... } \\
\text { Falling-tree scars. } \\
\text { Lightning scars.... } \\
\text { Sapsucker scars... } \\
\text { Blaze scars. ...... } \\
\text { Frost cracks ...... }\end{array}$} & \multirow{2}{*}{$\begin{array}{r}43 \\
25 \\
11 \\
1 \\
1 \\
0\end{array}$} & \multirow{2}{*}{$\begin{array}{r}237 \\
61 \\
38 \\
9 \\
0 \\
7\end{array}$} & \multirow{2}{*}{$\begin{array}{r}280 \\
86 \\
49 \\
10 \\
1 \\
7\end{array}$} & \multirow{2}{*}{$\begin{array}{r}55.1 \\
16.9 \\
9.6 \\
2.0 \\
.2 \\
1.4\end{array}$} & \multirow{2}{*}{$\begin{array}{l}\text { Spike tops....... } \\
\text { Broken tops .... } \\
\text { Unknown scars.. } \\
\text { Total ...... }\end{array}$} & 0 & & $\begin{array}{r}10 \\
58 \\
7 \\
\end{array}$ & $\begin{array}{r}2.0 \\
11.4 \\
1.4 \\
\end{array}$ \\
\hline & & & & & & & & 508 & \\
\hline
\end{tabular}

In Table 3 the healed-over, closed, or occluded scars are greatly in the majority. This indicates that the wounds were mostly superficial and that this tree species heals rapidly after wounding.

The predominance of fire scars is striking. While it was not possible to determine the years in which the fires occurred, for the reason stated previously, it was noticeable that most of the injuries of this nature had happened when the trees were relatively young-that is, below 20 inches diameter breast high, more or less. This coincides with our knowledge of fires in the Douglas fir region. In young stands fires which run over the surface of the ground injuring but not killing the trees are common, while in mature or overmature timber fires have a tendency to run through the crowns, killing all but scattered individuals outright.

Burls may form as the result of fire scars, but more common are swollen, or churn, butts as the result of severe scars.. These churn butts extend usually from the ground level up the trunk slightly higher than the limit of the fire scar. Even though a fire scar has been healed over for a long time and there is no churn butt or burl to indicate its presence, it can often be detected by the variation in the appearance of the bark over the healed wound. This appearance is hard to describe, but not difficult to judge after a little experience.

Next in numerical importance to fire scars were wounds caused by falling trees. These, of course, are more common in mature and overmature stands than in second growth. Trees may die and ultimately the snags will fall, or again large trees with butt-rot are quite subject to windfall. Such trees on their way down strike others, breaking off the tops or limbs or bruising the trunks and knocking off pieces of bark. Falling-tree scars rarely extend deeply
into the tree. 
Lightning wounds occasionally occurred, although the Douglas fir region is not subject to severe lightning storms. Injury by sapsuckers was rare, and the few scars found were very superficial. These birds do not seem to select a single tree and attack it year after year, as they often do in other tree species. Frost cracks were not common. This was to be expected, since the Douglas fir region as a whole is not subject to sudden extreme rariations of temperature from relatively warm to very cold.

There were 10 spike-topped trees. Half of these dead tops had been caused by lightning, while two of them resulted from falling trees.

On the other hand, trees with broken tops were not unusual. The most common cause of such injury was falling trees. This source accounted for 31 of the broken tops. Snow was responsible for 4 and lightning for 3 , while the remaining 20 could not be determined. A load of ice or heavy wet snow is of more importance in causing broken tops than appears from these figures, but most of the damage occurs in young stands. According to observations of the writer and others, heavy snow or ice injury occurred about $1888^{3}$ in the immediate section where this study' was made. The damage was very apparent from the number of broken tops, all having been made at the same time, in second-growth timber.

Broken tops require a long time to heal. Even after the volunteer top is well started the stub of the old top protrudes, and when this is finally grown over a slight crook still remains in the bole, which does not entirely disappear for years.

In considering the data presented, it may appear from the total of 508 scars on 158 trees that the trees were subject to excessive injury. It must be remembered that most of the wounds were superficial. Then, too, several small scars on a single tree might be made by the same agent. For example, one fire or one lightning stroke can readily cause several scars on a tree. Owing to the impossibility of determining with any accuracy the dates of injury in Douglas fir, it was necessary to consider each scar, with a few exceptions, as separate and distinct.

\section{ENTRANCE OF THE DECAYS.}

The wind-blown spores from sporophores of wood-destroying fungi attacking the heartwood of living trees must light on exposed dead wood in order to cause infection. But the type of infection court raries with different species of decay, and it is of importance to determine the common means of entrance in each case, since in so far as the infections occur through controllable mechanical injuries there is a possibility of reducing the amount of loss.

Table 4 shows the points of entrance for conk-rot. From this table it can be seen that knots or branch stubs are responsible for the major portion of the infections, and, what is far more important, all but an infinitesimal portion of the total volume of conk-rot resulted from these infections.

The infections of brown trunk-rot both numerically and in the resulting volume of decay were rather more evenly distributed, as can be seen from Table 5; but here again knots predominate.

3 This date is from an unpublished record furnished by the Forest Service. 
TABLE 4.-Infection court of conk-rot in Douglas fir.

\begin{tabular}{|c|c|c|c|c|c|c|}
\hline \multirow{4}{*}{ Infection court. } & \multicolumn{6}{|c|}{ Infections. } \\
\hline & \multirow{3}{*}{$\begin{array}{l}\text { Number, } \\
\text { basis. }\end{array}$} & \multicolumn{3}{|c|}{ Percentage of total. } & \multirow{2}{*}{\multicolumn{2}{|c|}{ A verage volume. }} \\
\hline & & \multirow{2}{*}{ Number. } & \multicolumn{2}{|c|}{ Volume. } & & \\
\hline & & & $\begin{array}{l}\text { Board } \\
\text { feet. }\end{array}$ & $\begin{array}{l}\text { Cubic } \\
\text { feet. }\end{array}$ & $\begin{array}{l}\text { Board } \\
\text { feet. }\end{array}$ & $\begin{array}{l}\text { Cubic } \\
\text { feet. }\end{array}$ \\
\hline $\begin{array}{l}\text { Knots .............. } \\
\text { Fire scars......... } \\
\text { Falling-tree wounds } \\
\text { Lightning scars .... } \\
\text { Dead tops........... } \\
\text { Unknown scars..... }\end{array}$ & $\begin{array}{r}98 \\
10 \\
3 \\
4 \\
1 \\
2\end{array}$ & $\begin{array}{r}83.0 \\
8.5 \\
2.5 \\
3.4 \\
.9 \\
1.7\end{array}$ & $\begin{array}{l}99.62 \\
.04 \\
0 \\
0 \\
0\end{array}$ & $\begin{array}{l}99.48 \\
.03 \\
.05 \\
.43 \\
0 \\
0\end{array}$ & $\begin{array}{r}796 \\
3 \\
0 \\
68 \\
0 \\
0\end{array}$ & $\begin{array}{l}77.0 \\
.2 \\
1.4 \\
8.2 \\
0 \\
0\end{array}$ \\
\hline
\end{tabular}

TABLE 5.-Infection court of trunk-rot in Douglas fir.

\begin{tabular}{|c|c|c|c|c|c|c|}
\hline \multirow{4}{*}{ Infection court. } & \multicolumn{6}{|c|}{ Infections. } \\
\hline & \multirow{3}{*}{$\begin{array}{c}\text { Number, } \\
\text { basis. }\end{array}$} & \multicolumn{3}{|c|}{ Percen tage of total. } & \multirow{2}{*}{\multicolumn{2}{|c|}{ A verage volume. }} \\
\hline & & \multirow{2}{*}{ Number. } & \multicolumn{2}{|c|}{ Volume. } & & \\
\hline & & & $\begin{array}{l}\text { Board } \\
\text { feet. }\end{array}$ & $\begin{array}{l}\text { Cubic } \\
\text { feet. }\end{array}$ & $\begin{array}{l}\text { Board } \\
\text { feet. }\end{array}$ & $\begin{array}{l}\text { Cubic } \\
\text { feet. }\end{array}$ \\
\hline $\begin{array}{l}\text { Knots ............ } \\
\text { Fire scars........ } \\
\text { Falling-tree scars. } \\
\text { Lightning scars.. }\end{array}$ & $\begin{array}{l}7 \\
2 \\
4 \\
2\end{array}$ & $\begin{array}{l}46.7 \\
13.3 \\
26.7 \\
13.3\end{array}$ & $\begin{array}{c}44.6 \\
0 \\
30.0 \\
25.4\end{array}$ & $\begin{array}{c}46.1 \\
0 \\
26.9 \\
26.9\end{array}$ & $\begin{array}{r}353 \\
0 \\
415 \\
705\end{array}$ & $\begin{array}{c}28.4 \\
0 \\
29.0 \\
58.0\end{array}$ \\
\hline
\end{tabular}

Table 6 brings out the relation between fire and red-brown butt-rot. The major portion of the infections entered through fire scars, and the resulting volume of decay was proportionately much higher. This butt-rot also attacks the roots and can probably be spread by the contact of a diseased root with a sound one. About 11 per cent of the volume of rot is apparently traceable to this method of infection. Besides these two the other infection courts are of no importance.

TABLe 6.-Infection court of butt-rot in Douglas fir.

\begin{tabular}{|c|c|c|c|c|c|c|}
\hline \multirow{4}{*}{ Infection court. } & \multicolumn{6}{|c|}{ Infections. } \\
\hline & \multirow{3}{*}{$\begin{array}{l}\text { Number, } \\
\text { basis. }\end{array}$} & \multicolumn{3}{|c|}{ Percentage of total. } & \multirow{2}{*}{\multicolumn{2}{|c|}{ Arerage volume. }} \\
\hline & & \multirow{2}{*}{ Number. } & \multicolumn{2}{|c|}{ Volume. } & & \\
\hline & & & $\begin{array}{l}\text { Board } \\
\text { feet. }\end{array}$ & $\begin{array}{l}\text { Cubic } \\
\text { feet. }\end{array}$ & $\begin{array}{l}\text { Board } \\
\text { feet. }\end{array}$ & $\begin{array}{l}\text { Cubic } \\
\text { feet. }\end{array}$ \\
\hline $\begin{array}{l}\text { Knots ............ } \\
\text { Fire scars......... } \\
\text { Falling-tree scars. } \\
\text { Lightning scars... } \\
\text { Roots ............ } \\
\text { Unknown scars... }\end{array}$ & $\begin{array}{r}1 \\
41 \\
4 \\
4 \\
16 \\
4\end{array}$ & $\begin{array}{r}1.4 \\
58.6 \\
5.7 \\
5.7 \\
22.9 \\
5.7\end{array}$ & $\begin{array}{r}1.4 \\
78.2 \\
3.7 \\
2.5 \\
10.8 \\
3.4\end{array}$ & $\begin{array}{r}0.5 \\
79.1 \\
5.0 \\
1.8 \\
11.5 \\
2.1\end{array}$ & $\begin{array}{l}60 \\
83 \\
40 \\
28 \\
29 \\
38\end{array}$ & $\begin{array}{l}2.0 \\
8.0 \\
5.2 \\
1.8 \\
3.6 \\
2.2\end{array}$ \\
\hline
\end{tabular}


Yellow-brown top-rot, true to its name, in Table 7 shows the greatest number of infections entering through dead tops, which include broken and spike tops. Knots, though with fewer infections, were responsible for a greater volume of decay, since such infections usually occurred lower down on the bole where there was more heartwood for the fungus to work on than was the case when the wood destroyer entered through a dead top. The large volume of decay the cause of which is recorded as "unknown" resulted from an extensive infection which could not be traced to its source.

TABLE 7.-Infection court of yellow-brown top-rot in Douglas fir.

\begin{tabular}{|c|c|c|c|c|c|c|}
\hline \multirow{4}{*}{ Infection court. } & \multicolumn{6}{|c|}{ Infections. } \\
\hline & \multirow{3}{*}{$\begin{array}{c}\text { Number, } \\
\text { basis. }\end{array}$} & \multicolumn{3}{|c|}{ Percentage of total. } & \multirow{2}{*}{\multicolumn{2}{|c|}{ A verage volume. }} \\
\hline & & \multirow{2}{*}{ Number. } & \multicolumn{2}{|c|}{ Volume. } & & \\
\hline & & & $\begin{array}{l}\text { Board } \\
\text { feet. }\end{array}$ & $\begin{array}{l}\text { Cubic } \\
\text { feet. }\end{array}$ & $\begin{array}{l}\text { Board } \\
\text { feet. }\end{array}$ & $\begin{array}{l}\text { Cubic } \\
\text { feet. }\end{array}$ \\
\hline $\begin{array}{l}\text { Knots ............ } \\
\text { Fire scars........ } \\
\text { Falling-tree scars. } \\
\text { Lightning scars... } \\
\text { Dead tops......... } \\
\text { Unknown........ }\end{array}$ & $\begin{array}{r}12 \\
2 \\
7 \\
5 \\
18 \\
2\end{array}$ & $\begin{array}{r}26.1 \\
4.3 \\
15.2 \\
10.9 \\
39.1 \\
4.3\end{array}$ & $\begin{array}{r}35.8 \\
8.2 \\
7.0 \\
15.4 \\
17.0 \\
16.7\end{array}$ & $\begin{array}{r}35.7 \\
6.6 \\
1.9 \\
15.0 \\
23.8 \\
17.0\end{array}$ & $\begin{array}{r}98 \\
135 \\
33 \\
102 \\
31 \\
275\end{array}$ & $\begin{array}{r}9.6 \\
10.6 \\
.9 \\
9.7 \\
4.3 \\
27.5\end{array}$ \\
\hline
\end{tabular}

Table 8 shows the infection courts of the unknown decays. Some of these were undoubtedly infections of the four common rots, but were abnormal or so small that they could not be accurately identified.

TABLE 8.-Infection court of unknown rots in Douglas fir.

\begin{tabular}{|c|c|c|c|c|c|c|}
\hline \multirow{4}{*}{ Infection court. } & \multicolumn{6}{|c|}{ Infections. } \\
\hline & \multirow{3}{*}{$\begin{array}{c}\text { Number, } \\
\text { basis. }\end{array}$} & \multicolumn{3}{|c|}{ Percentage of total. } & \multirow{2}{*}{\multicolumn{2}{|c|}{ A verage volume. }} \\
\hline & & \multirow{2}{*}{ Number. } & \multicolumn{2}{|c|}{ Volume. } & & \\
\hline & & & $\begin{array}{c}\text { Board } \\
\text { feet. }\end{array}$ & $\begin{array}{l}\text { Cubic } \\
\text { feet. }\end{array}$ & $\begin{array}{l}\text { Board } \\
\text { f eet. }\end{array}$ & $\begin{array}{l}\text { Cubic } \\
\text { feet. }\end{array}$ \\
\hline $\begin{array}{l}\text { Knots ........... } \\
\text { Fire scars ....... } \\
\text { Lightning scars } \\
\text { Dead tops........ } \\
\text { Roots ............. }\end{array}$ & $\begin{array}{r}5 \\
12 \\
4 \\
11 \\
3\end{array}$ & $\begin{array}{r}14.3 \\
34.3 \\
11.4 \\
31.4 \\
8.6\end{array}$ & $\begin{array}{c}0 \\
80.0 \\
20.0 \\
0 \\
0\end{array}$ & $\begin{array}{r}0 \\
62.5 \\
8.8 \\
20.8 \\
7.8\end{array}$ & $\begin{array}{r}0 \\
10 \\
8 \\
0 \\
0\end{array}$ & $\begin{array}{l}0 \\
1.8 \\
.8 \\
.6 \\
.9\end{array}$ \\
\hline
\end{tabular}

In Table 9 the data in Tables 4 to 8, inclusive, have been combined. Knots were responsible for the greatest number of infections and a proportionately greater loss through decay.

Of all the infection courts fire scars, which were only responsible for 4.2 per cent of the total rot volume, are the only factors that can be directly controlled. With the increase of efficiency in fire-protection methods, injury from fires is being steadily reduced. But the other 95.8 per cent of the decay is traceable to sources that can not be controlled. Knots, falling trees, lightning, and snow or ice will 
be present in Douglas fir stands in the future, no matter how well regulated. Consequently, the reduction in the quantity of rot in Douglas fir by a reduction in the scars caused by controllable mechanical injuries can amount to little.

TABLE 9.-Infection court of combined decays in Douglas fir.

\begin{tabular}{|c|c|c|c|c|c|c|}
\hline \multirow{4}{*}{ Infection court. } & \multicolumn{6}{|c|}{ Infections. } \\
\hline & \multirow{3}{*}{$\begin{array}{l}\text { Number, } \\
\text { basis. }\end{array}$} & \multicolumn{3}{|c|}{ Percentagc of total. } & \multirow{2}{*}{\multicolumn{2}{|c|}{$\Lambda$ verage volume. }} \\
\hline & & \multirow{2}{*}{ Number. } & \multicolumn{2}{|c|}{ Volume. } & & \\
\hline & & & $\begin{array}{l}\text { Board } \\
\text { fect. }\end{array}$ & $\begin{array}{l}\text { Cubic } \\
\text { feet. }\end{array}$ & $\begin{array}{l}\text { Board } \\
\text { feet. }\end{array}$ & $\begin{array}{l}\text { Cubic } \\
\text { fect. }\end{array}$ \\
\hline 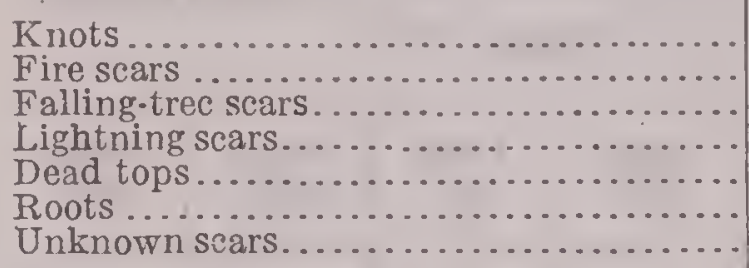 & $\begin{array}{r}123 \\
67 \\
18 \\
19 \\
30 \\
19 \\
8\end{array}$ & $\begin{array}{r}43.3 \\
23.6 \\
6.3 \\
6.7 \\
10.6 \\
6.7 \\
2.8\end{array}$ & $\begin{array}{r}89.2 \\
4.2 \\
2.2 \\
2.5 \\
.6 \\
.5 \\
.8\end{array}$ & $\begin{array}{r}89.2 \\
4.2 \\
1.7 \\
2.4 \\
1.0 \\
.6 \\
.7\end{array}$ & $\begin{array}{r}664 \\
57 \\
114 \\
123 \\
19 \\
25 \\
88\end{array}$ & $\begin{array}{r}63.9 \\
5.5 \\
8.2 \\
11.5 \\
2.8 \\
2.6 \\
8.0\end{array}$ \\
\hline
\end{tabular}

While it is true that infection courts resulting from all mechanical injuries are of little importance in the total volume of decay produced as compared to knots or branch stubs, it is of academic interest to determine the kind of scar most susceptible to infection in the trees studied. This is brought out in Table 10.

TABle 10.-Susceptibility to infection of various scars in Douglas fir.

\begin{tabular}{|c|c|c|c|c|c|c|c|}
\hline \multirow{2}{*}{ Type of scar. } & \multirow{2}{*}{$\begin{array}{l}\text { Number } \\
\text { of scars. }\end{array}$} & \multicolumn{2}{|c|}{ Scars infected. } & \multirow{2}{*}{ Type of scar. } & \multirow{2}{*}{$\begin{array}{l}\text { Number } \\
\text { of scars. }\end{array}$} & \multicolumn{2}{|c|}{ Scars infected. } \\
\hline & & Number. & Per cent. & & & Number. & Pcr cent. \\
\hline \multirow{2}{*}{$\begin{array}{l}\text { Fire scars.......... } \\
\text { Falling-trce scars. } \\
\text { Lightning scars ... } \\
\text { Sapsucker scars ... } \\
\text { Blaze scars ........ } \\
\text { Frost cracks...... }\end{array}$} & \multirow{2}{*}{$\begin{array}{r}280 \\
86 \\
49 \\
10 \\
1 \\
7\end{array}$} & \multirow{2}{*}{$\begin{array}{r}67 \\
18 \\
19 \\
0 \\
0 \\
0\end{array}$} & \multirow{2}{*}{$\begin{array}{c}23.9 \\
20.9 \\
38.8 \\
0 \\
0 \\
0\end{array}$} & \multirow{2}{*}{$\begin{array}{l}\text { Spike tops ......... } \\
\text { Broken tops ...... } \\
\text { Unknown scars ... } \\
\text { Total ........ }\end{array}$} & $\begin{array}{r}68 \\
7\end{array}$ & $\begin{array}{r}30 \\
7\end{array}$ & $\begin{array}{l}44.1 \\
100\end{array}$ \\
\hline & & & & & 508 & 141 & $2 S .0$ \\
\hline
\end{tabular}

Dead tops, which include spike-tops and broken tops, followed by lightning scars, were most susceptible to infection, according to Table 10.

\section{INDICATIONS OF DECAY IN LIVING TREES.}

Recognition of the indications of decay in standing Douglas fir or in logs is of the greatest importance from a practical standpoint. A comparison of the cruise and actual cut on many operations in overmature decadent timber brings this out forcibly. At present there is a great deal of confusion and misinformation among foresters and lumbermen in regard to the detection of decay in living trees, and the specter of "hidden defect" assumes unnecessary proportions. In fact, decay in Douglas fir is more easily detected than in most species subject to a large amount of rot. 


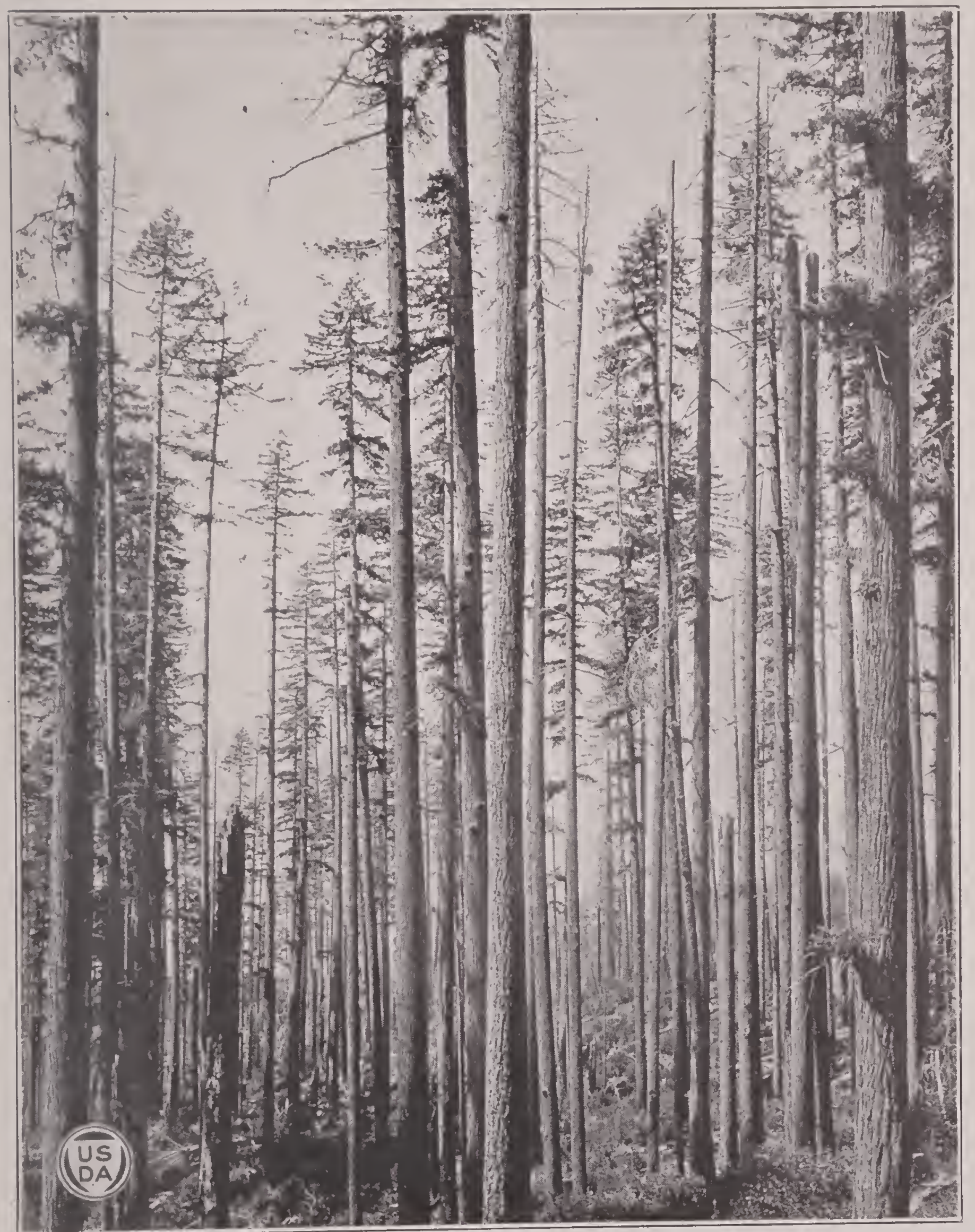

Defective Douglas Firs Left Standing AFter Logging. The principal defect is decay caused by the ring-scale fungus. 


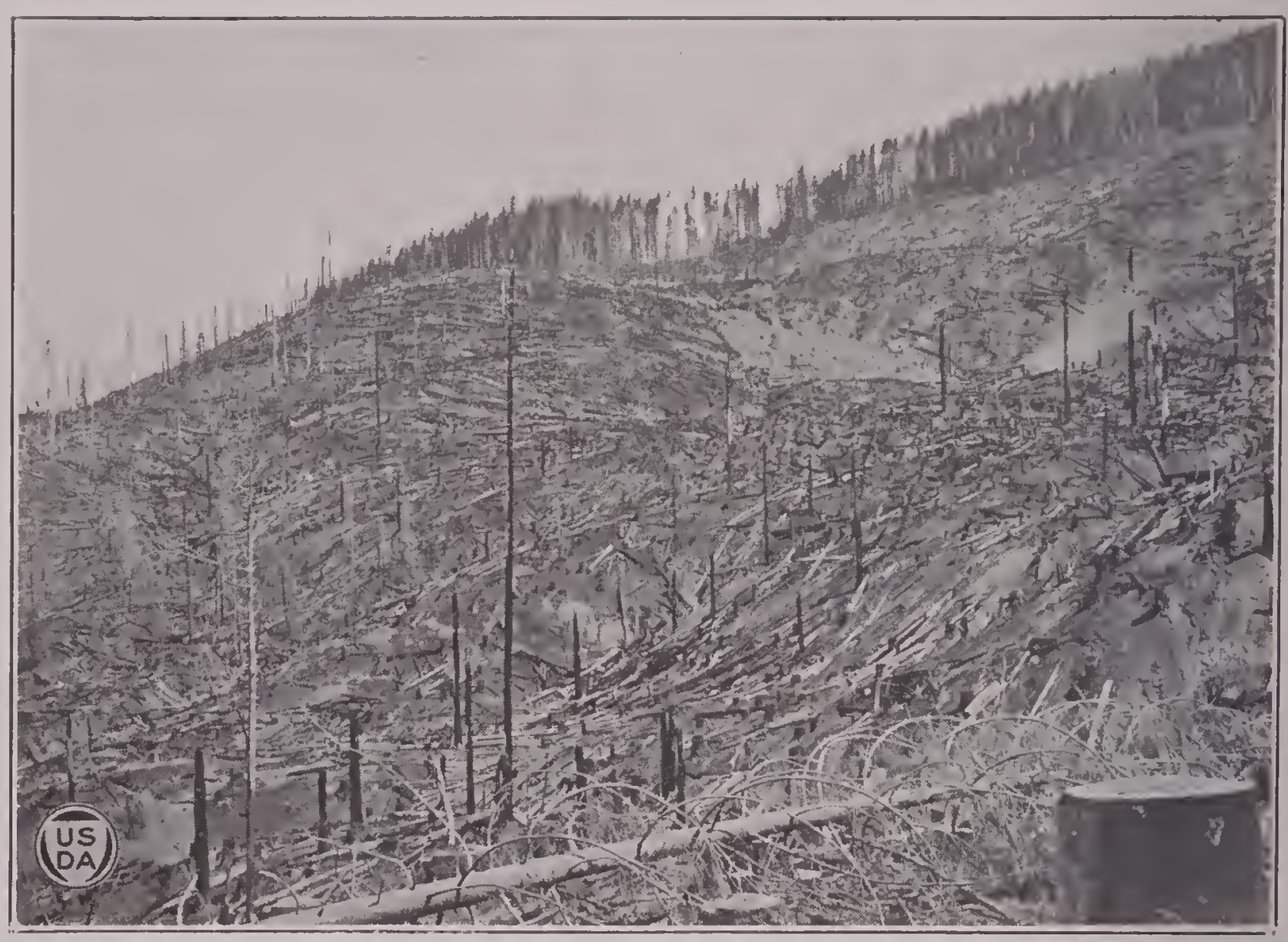

A Practically Pure Stand of Overmature douglas fir after LOGGING.

Nearly all the large pieces were left because of rot, principally decay caused by the ring-scalc fungus. (Photographed by D.C. Ingram.) 


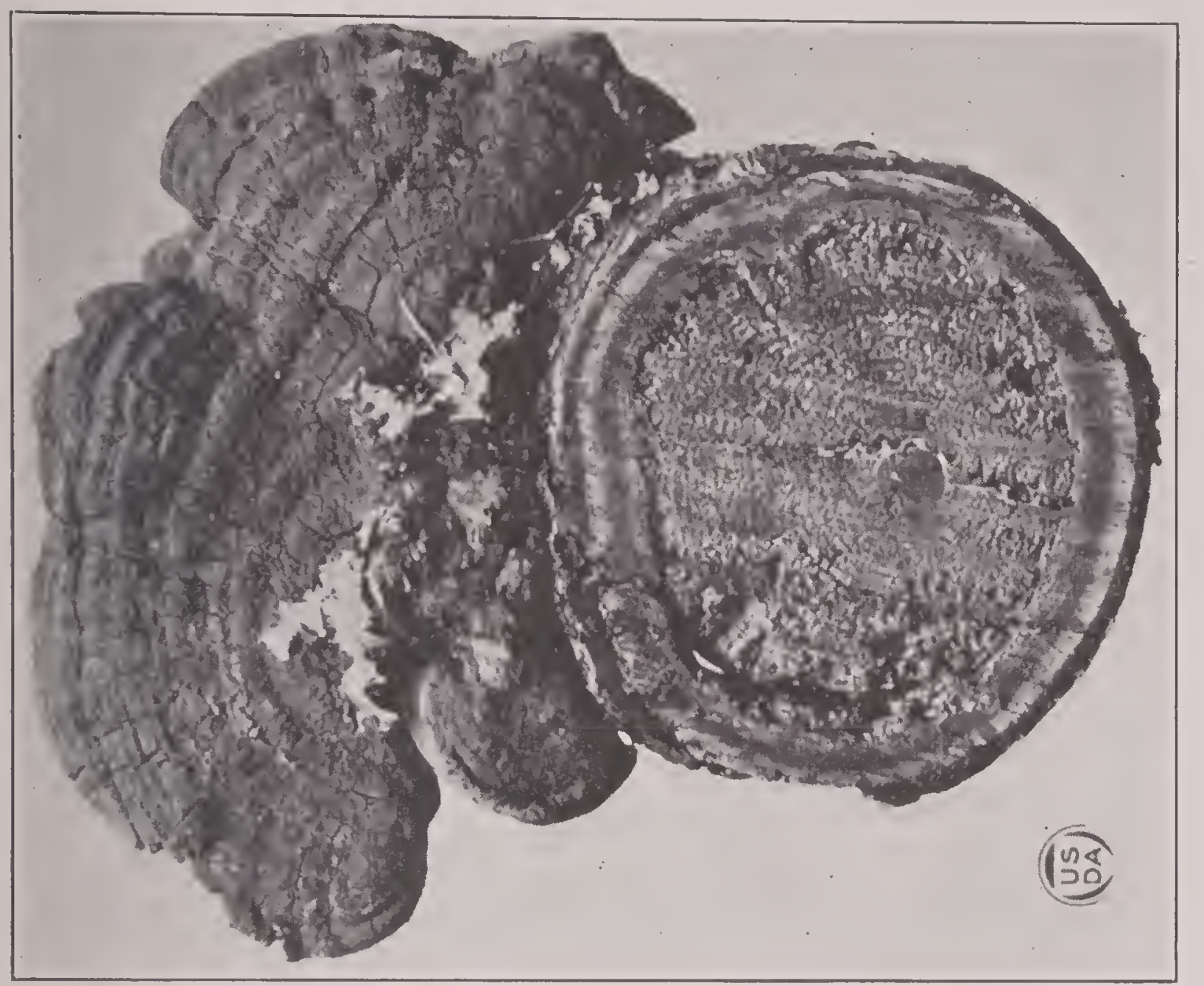

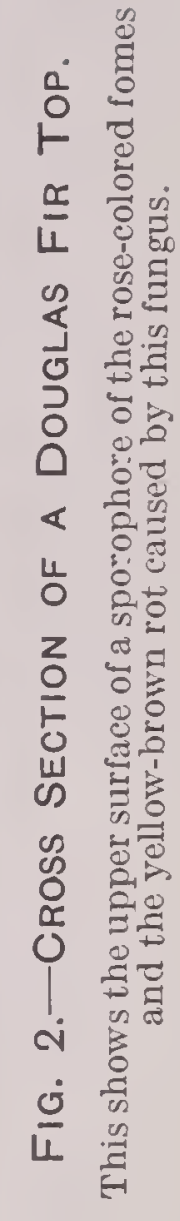

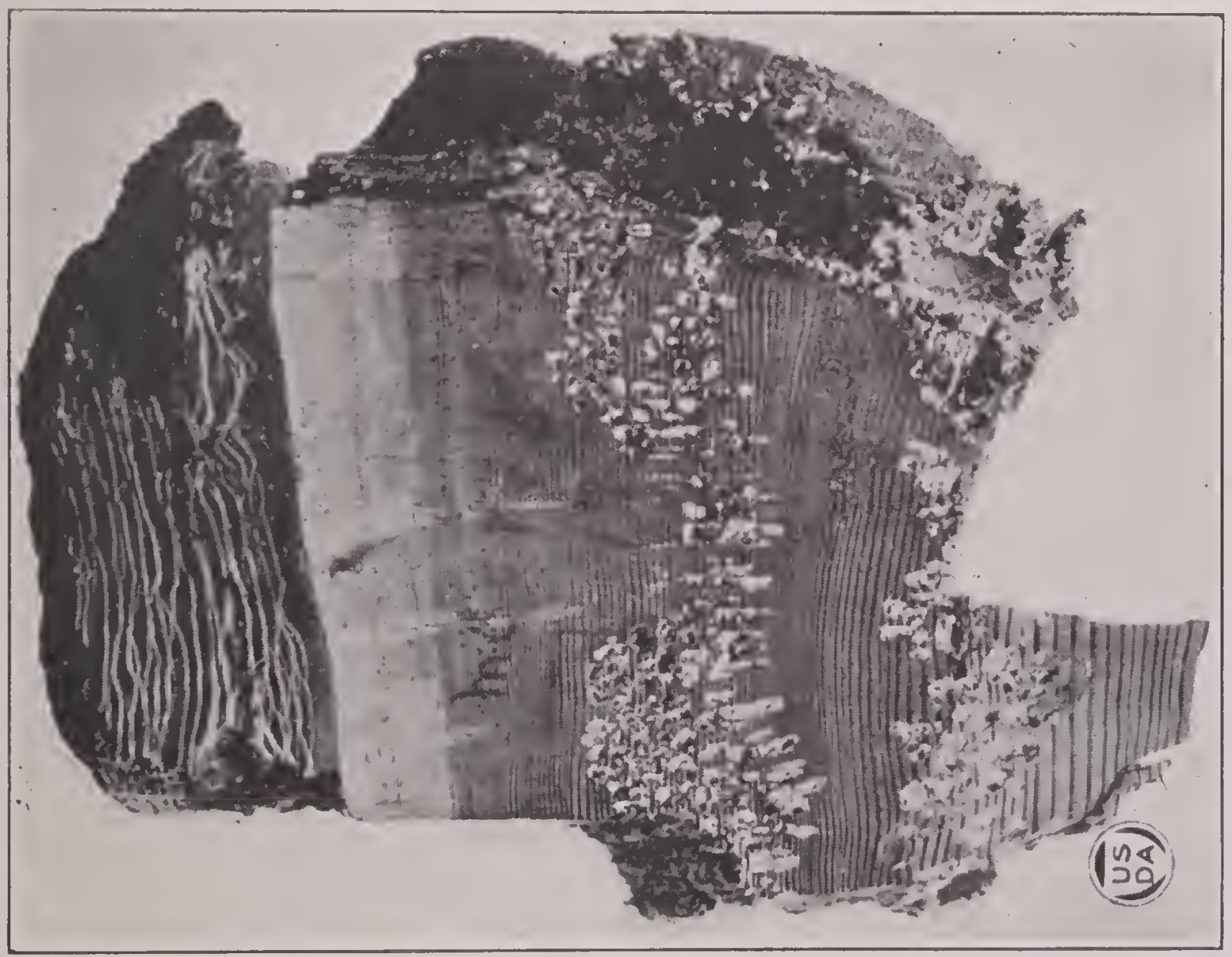

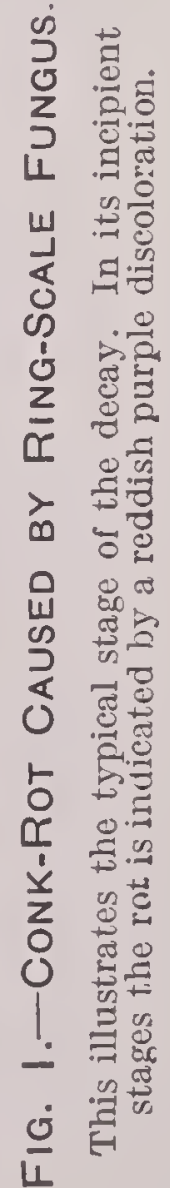




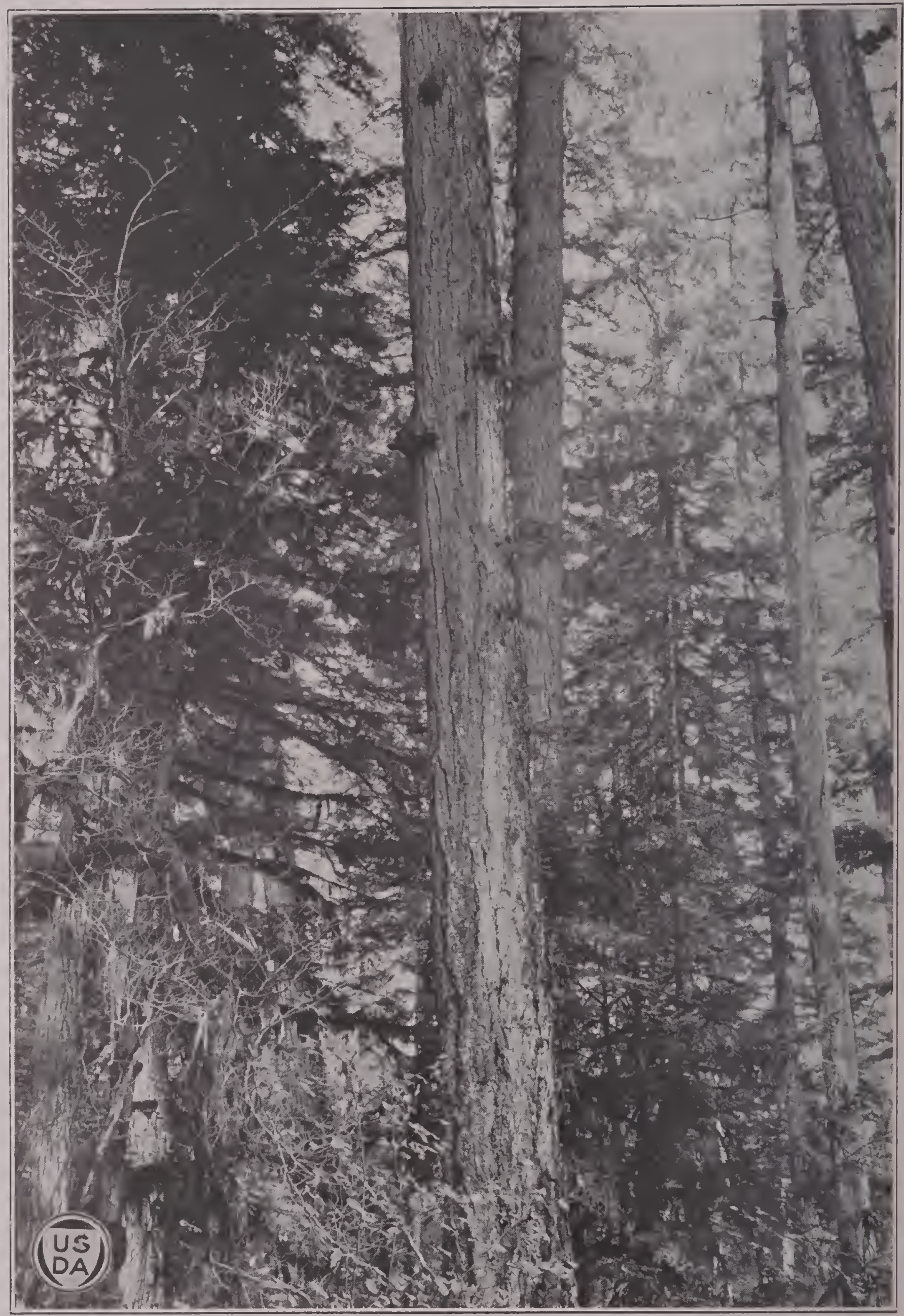

SPOROPHORES OF THE RING-SCALE Fungus, Indicating Conk-Rot IN THE HEARTWOOD OF THE TREE.

(Photographed by G. G. Hedgcock.) 


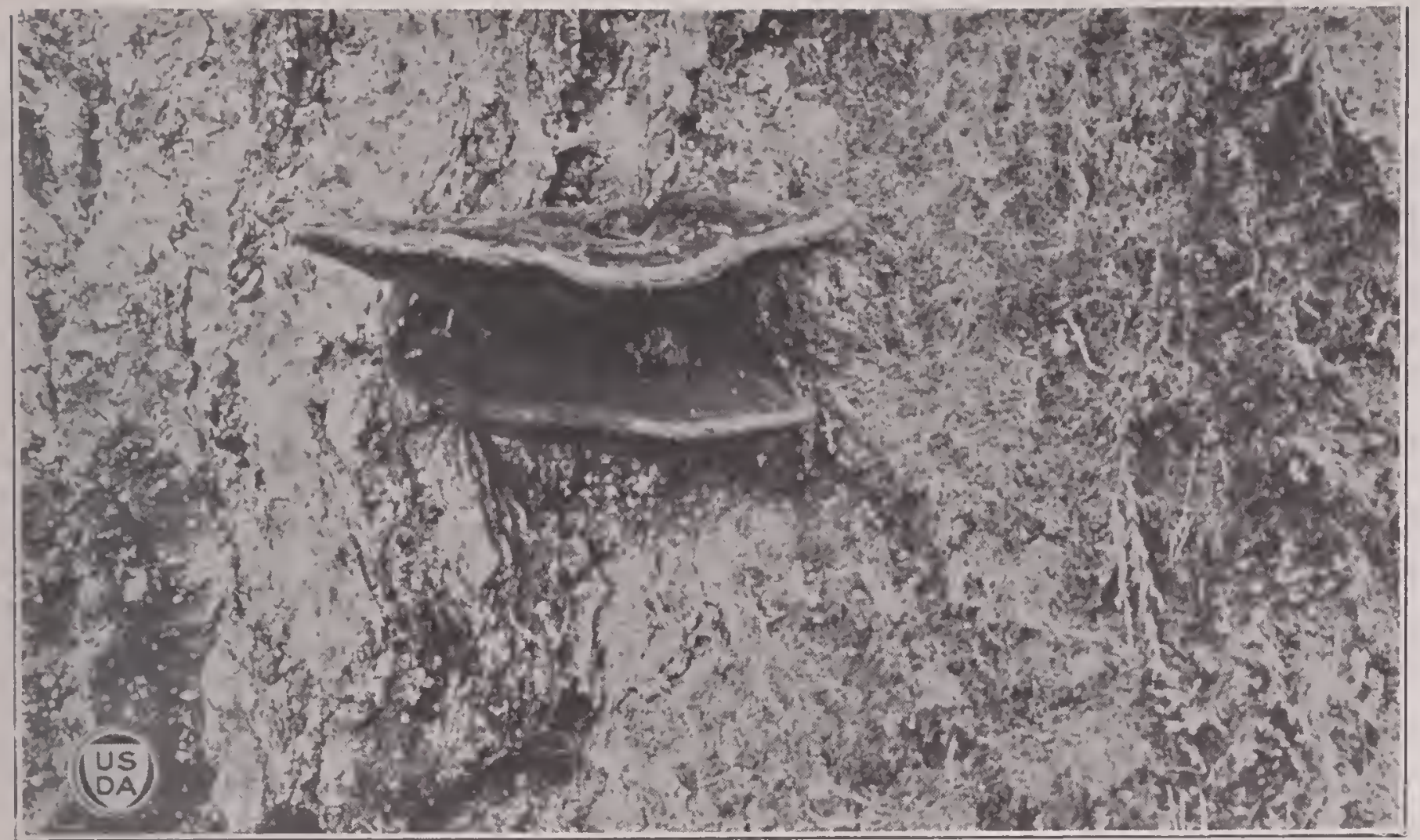

FIG. I.-SPOROPHORES OF THE VELVET-TOP FUNGUS ON THE BUTT OF A LIVING DOUGLAS FIR.

These spo:opho:es indicatc red-brown butt-rot in the trec. (Photographed by G. G. Hedgcock.)

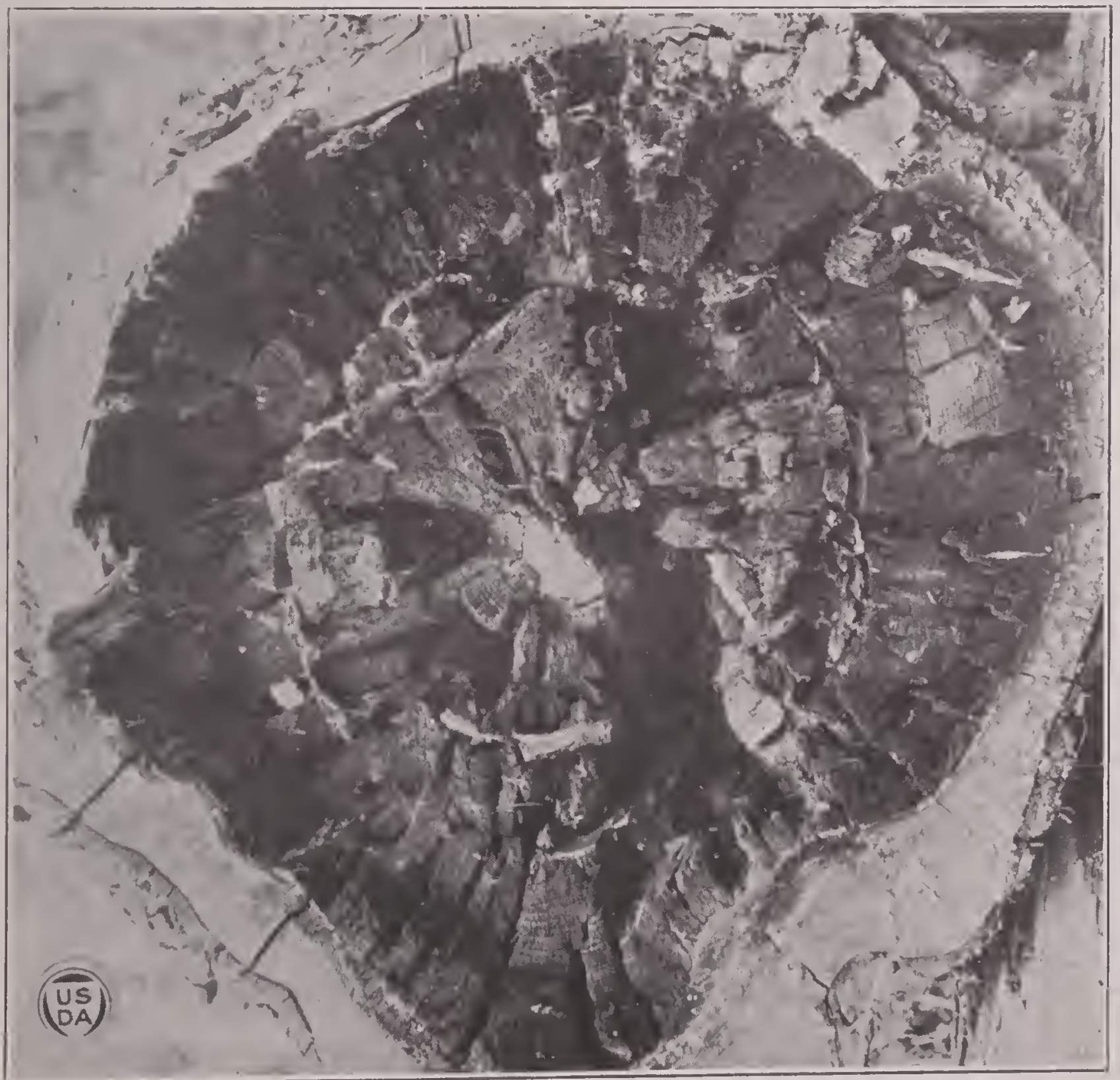

FIG. 2.-RED-BRown BUtT-Rot CAused BY the VELVET-ToP Fungus.

Only a thin shell of sapwood remains. Trees so badly decayed are subject to windfall, particularly if the rot extends into the roots. (Photographed by G. G. Hedgcock.) 


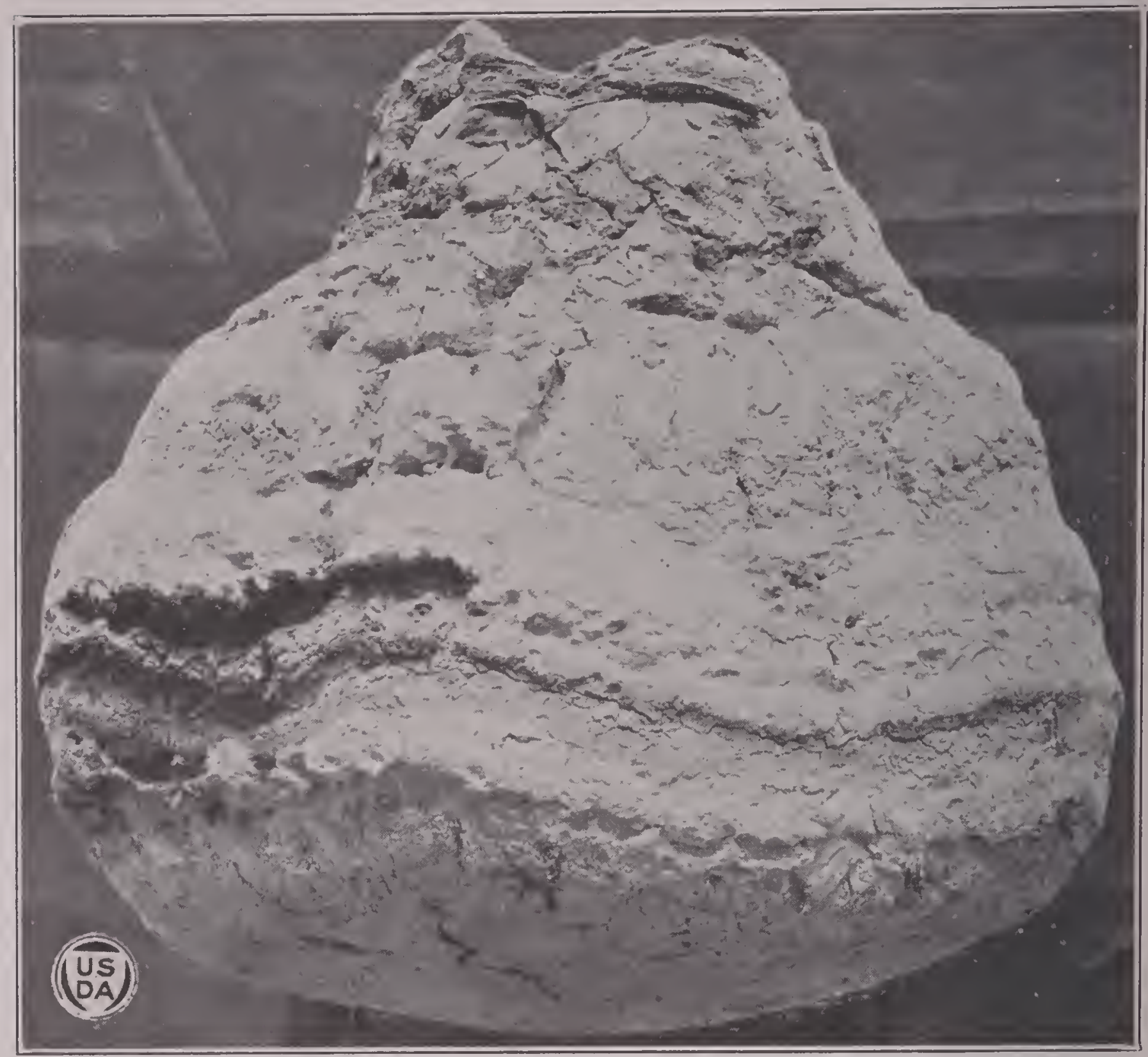

FIG. I.-SPOROPHORE OF THE QUININE FUNGUS.

These eonspicuous whitish fruiting bodies are not common on living trees, but are found more often on dead down timber. The sporophore has a very bitter taste.

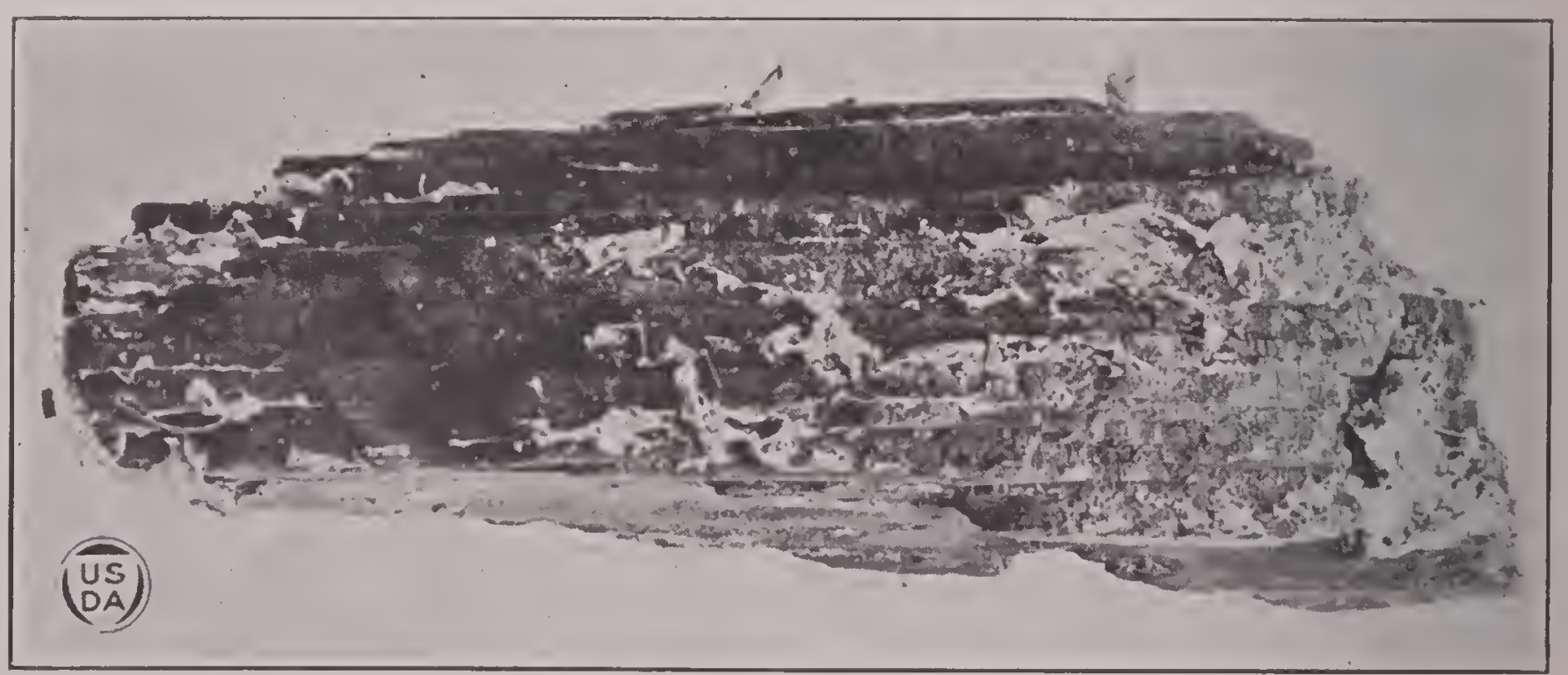

Fig. 2.-Brown Trunk-Rot Caused by the Quinine Fungus.

The decay is usually extensive in an infeeted tree. 


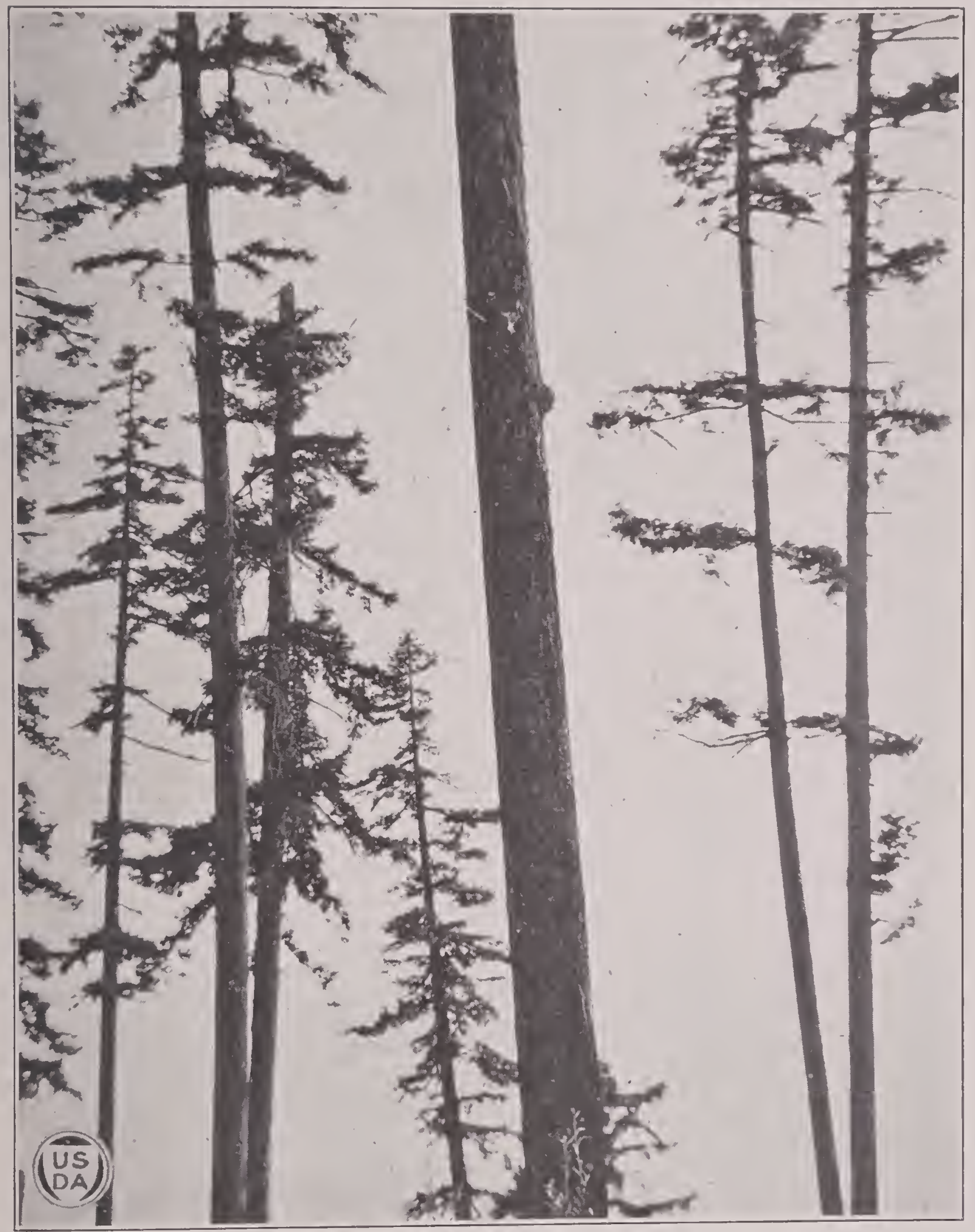

BURL ON A DOUglas FIR LEFT STANDING ON A CUT-OVER AREA.

Beeause of the burl the tree was thought to be badly decayed. Burls do not indicate decay Compare with Plate VIII. 


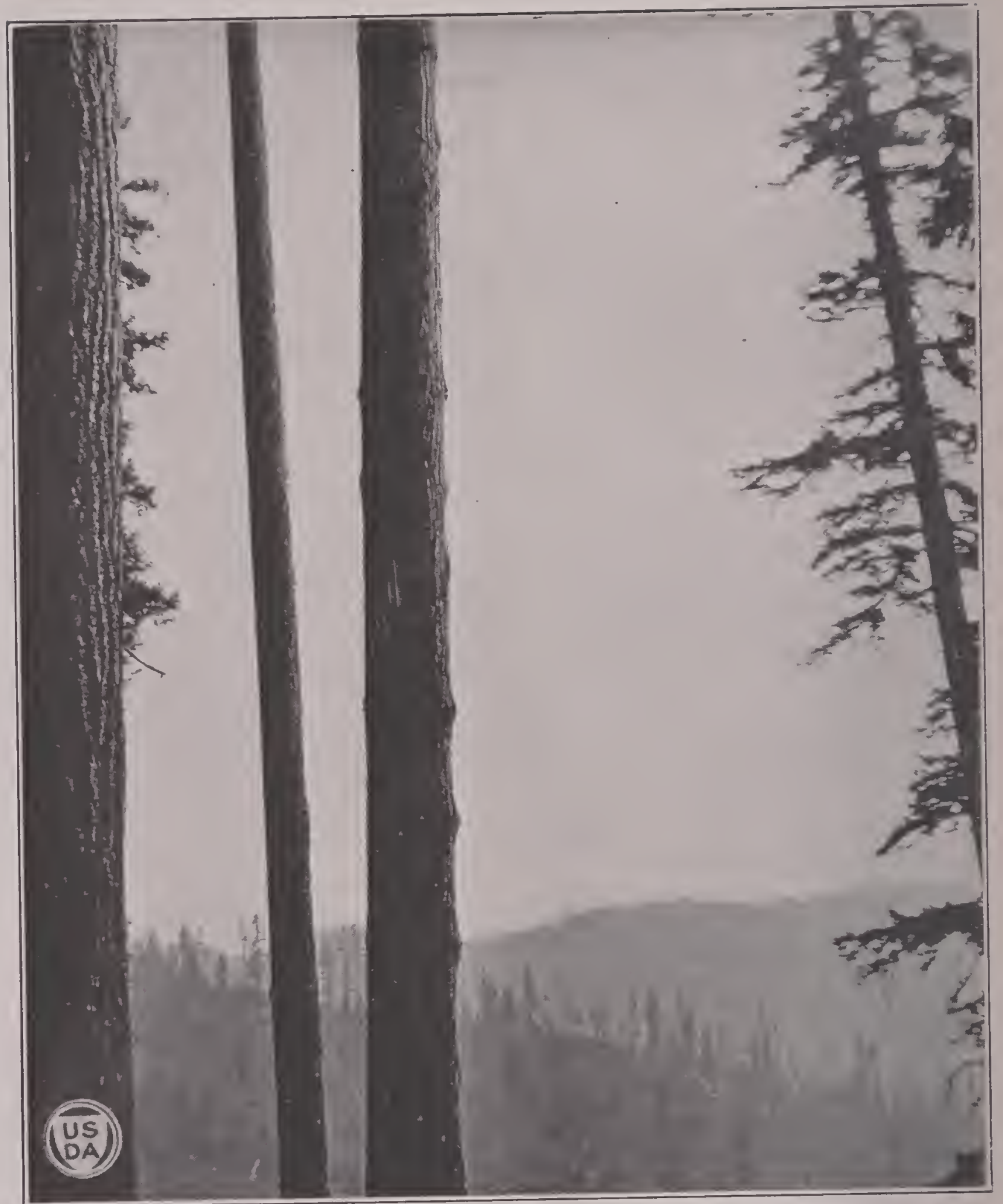

SWOLLEN KNOTS OR BLIND CONKS ON DOUGLAS FIR.

These indicate conk-rot in the tree. Compare with Plate viI. 
DEAD LIMBS.

Large trees with many dead limbs in the lower crown are no more likely to be decayed than a normal tree. Such "wolf trees," as they are known to the forester, merely grew faster than their neighbors, and their branches did not die so soon through lack of light; consequently it requires a longer time for these large limbs to drop off and for the branch stub to heal over.

\section{BRANCH FANS.}

Groups of branches, radiating like a fan from one point, are not uncommon on Douglas fir. These branch fans have been considered by some persons as indications of decay. A little thought will show that this is not within the realm of probability. That decay in the dead heartwood could directly affect the vital growing portion of the trunk of a tree in such a way as to cause abnormal branching is directly contrary to all our knowledge of growth and development of trees. In all, these branch fans were found on 32 trees, varying from 1 to 15 on a single tree, with an average of 4.4 . Of these 32 trees, 2 were free from decay, while in 19 the infections were very light, rarely causing a loss of more than 10 board feet, and the branch fans were not on the same portion of the trunk as the decay. There was a considerable volume of decay in each of the 11 remaining trees, but in 7 of these the decay was in the lower or middle portion of the trunk, while the branch fans were above it in the crown. In only 4 trees were part or all of the branch fans found on the decayed section of the trunk. These figures indicate the complete lack of even an empirical relation between branch fans and decay.

\section{BURLS.}

Douglas fir when bruised is subject to burls at the point of injury, but it is questionable whether or not all burls are caused by wounding. Such burls are a disorganized mass of wood tissue with a gnarled or twisted grain. This formation is a direct response to the irritation caused by the injury. Burls are often considered to indicate decay. Plate VII shows a tree left uncut on a logging operation because it was presumed from the presence of the burl that the tree was badly decayed. Data showing the relation of decay to burls in the trees studied are presented in Table 11. The number of burls to the tree varied from 1 to 20, with an average of 3.6.

TABle 11.--Relation of burls to decay in Douglas fir.

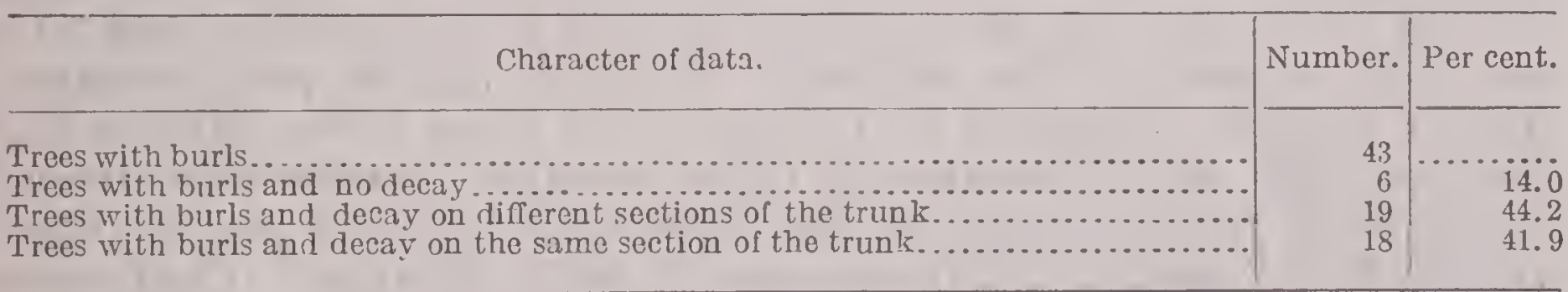

Analysis of the data in Table 11 demonstrates that the presence of burls does not mean decay in the tree. Of the trees with burls 14 per cent were free from decay, while in 44.2 per cent the rot and burls did not occupy the same section of the bole. Burls on the butt of the tree, however, are sometimes an indication of decay, since burls in this position often result from wounding by fire, and fire scars are quite commonly infected with red-brown butt-rot. 
CONK-ROT.

The decay causing by far the greatest loss in Douglas fir is relatively easy to detect. Sporophores of this decay occur abundantly. 'This is indicated by the local name of conk-rot used in the Pacific Northwest. Lumbermen observed the unusually common occurrence of sporophores, or "conks," on infected trees, as compared to those with other decays, and the name followed. The prolific development of sporophores is shown by the fact that of 83 trees with sporophores there was an average of 14.4 per tree, or a total of 1,196. Considering all infections both with and without sporophores there was an average of 10.1 sporophores per infection, or 1 for every 6.34 cubic feet of conk-rot in the trees and 1 for every 65 board feet.

It is of interest to consider the orientation of these sporophores. Möller (4), working with the same fungus, found 89.4 per cent of the sporophores on the westerly side of the trees. He explained this by the facts that the prevailing winds were from the west and the trees were most strongly struck by rain on the west side, and consequently the branch stubs (a very common point of infection) were more moist on that side. Weir and Hubert $(7$, p. 30), in their work with the Indianpaint fungus (Echinodontium tinctorium E. and E.) on western hemlock (Tsuga heterophylla (Raf.) Sarg.), found that most of the sporophores had a northwest to north-northeast orientation. The same workers (8, p. 18), studying conk-rot in western white pine (Pinus monticola Doug.), found the largest percentage of the sporophores develope a on the west side of the tree, with the smallest percentage on the southeast side. Table 12 shows the orientation of the sporophores on the trees studied.

TABLE 12.-Orientation of sporophores of conk-rot in Douglas fir.

\begin{tabular}{|c|c|c|c|c|c|c|c|c|}
\hline \multirow{2}{*}{+1} & \multicolumn{8}{|c|}{ Orientation of sporophores. } \\
\hline & NW. & N. & NE. & E. & $\mathrm{SE}$. & S. & SW. & W. \\
\hline $\begin{array}{l}\text { Number of sporophores } \\
\text { Percentage of total ... }\end{array}$ & $\begin{array}{r}212 \\
17.8\end{array}$ & $\begin{array}{r}291 \\
24.4\end{array}$ & $\begin{array}{r}202 \\
17.0\end{array}$ & $\begin{array}{r}91 \\
7.6\end{array}$ & $\begin{array}{r}144 \\
12.1\end{array}$ & $\begin{array}{r}77 \\
6.5\end{array}$ & $\begin{array}{r}96 \\
8.1\end{array}$ & $\begin{array}{r}79 \\
6.6\end{array}$ \\
\hline
\end{tabular}

The largest percentage of sporophores occurred on the north side of the trees and the smallest percentage on the south side. Adding the sporophores on the north, northwest, and northeast it is seen that 59.2 per cent were in the northerly grouping. Following this system gives 36.7 per cent easterly, 26.7 per cent southerly, and 32.5 per cent westerly. The northerly direction clearly predominates. This is logically explained by the fact that there is less light on the northerly side and consequently more moisture, particularly during the growing season, which in this region is a long dry period interrupted by occasional thundershowers of brief duration. Conditions on the northerly side of the trees are therefore more favorable for infection and the subsequent development of sporophores.

As a rule very little rot develops in a tree before a sporophore appears, or if not a sporophore at least a swollen knot, or "blind conk," as it is colloquially termed. The sporophores can not penetrate the unbroken bark and issue only through knnts or branch 
stubs not yet occluded. A swollen knot is the initial stage of a sporophore in which the substance forming the conk is growing out through a knot and forcing out the bark. The pressure may also cause an increase in the width of the sapwood immediately around the knot, which accentuates the swelling. Swollen knots are illustrated in Plate VIII. A swollen knot is just as good an indication of the presence of decay as a sporophore. Often the sporophore nerer develops beyond this stage, remaining abortive. Chopping into one of these knots reveals a brown, soft, corky or punky context, the same as in a fully developed sporophore. Plate III, Figure 1, shows a section through part of a decayed knot.

The effect of fire on sporophores or swollen knots is striking. When mature timber is swept by fire, the flames running along the trunk of the tree can not burn off the thick bark. However, the corky context of the sporophores and decayed knots burns readily, and this results in rounded, blackened hollows extending for several inches into the tree where the fire has burned out the decayed knots. This makes it possible to judge in a.measure the extent of conk-rot in recently fire-killed Douglas fir.

That the development of swollen knots and sporophores follows rather closely the progress of conk-rot in the heartwood is brought out in Table 13.

TABLE 13.-Relation of sporophores and swollen knots to conk-rot in Douglas fir.

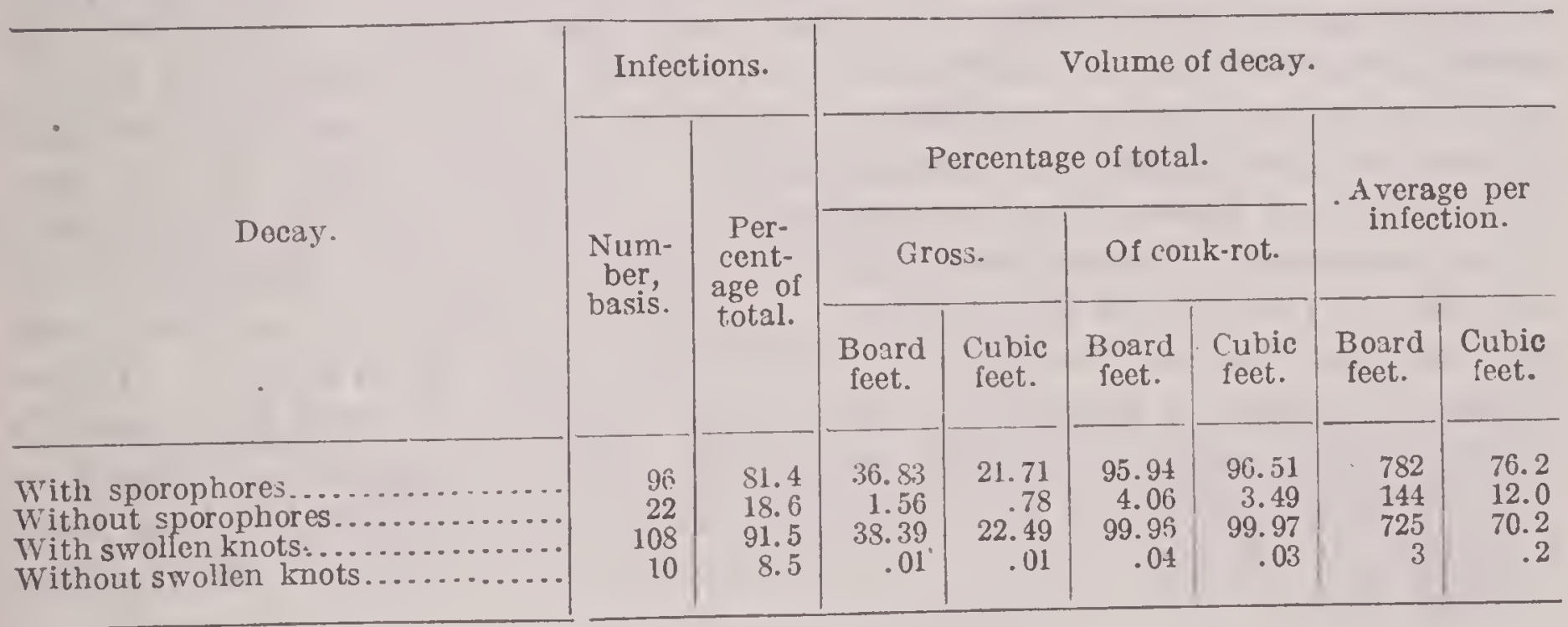

Table 13 shows that while there was a noticeable percentage of the infections which did not develop sporophores, these infections were very small, as is indicated by the volume percentages and the average volume per infection. The relation is even more striking with swollen knots, where the volume percentages and the average volume per infection of those infections without swollen knots is so small as to be negligible.

This means, then, that it is possible to pick out rather accurately the trees in a stand affected with conk-rot. When high up in a tree among the branches swollen knots, or even sporophores, are not easily seen, but if overlooked there it does not make so much difference in the accuracy of an estimate, since the volume of the top logs is relatively insignificant in the total.

EXTENT OF CONK-ROT.

It is not only possible to pick out the decayed trees, but it is also feasible to judge with some exactness the normal extent of conk-rot. 
In the trees studied it was found that the average extent of decay, including typical and incipient decay, above the highest sporophore was 20.1 feet. This was based on 83 infections. In two infections the decay ended at the height of the top sporophore, and in one tree the rot extended for 61 feet above the highest sporophore. When the downward extent of conk-rot below the lowest sporophore was considered, it was necessary to discard those infections in which the decay extended into the stump. Based on only 33 infections, the average downward extent was 13.9 feet. The average of both upward and downward combined was 18.3 feet.

The same figures for the highest and lowest swollen knots were as follows: Upward extent, 9.5 feet, based on 93 infections; downward extent, 9.2 feet based on 41 infections; combined average, 9.4 feet. In one tree the rot extended for 45.2 feet below the lowest swollen knot. This difference in the extent of decay beyond sporophores as compared to swollen knots is due to the fact that the swollen knot in many instances is the initial stage in the development of a normal sporophore, and consequently by the time a sporophore appears the decay has been in the tree longer and has progressed farther than at the formation of a swollen knot.

These data mean, then, that it is possible to approximate the volume of conk-rot in defective trees when cruising. The figures, of course, should not be applied to an individual tree as such, but should be used in estimating the individual components of a stand in order to secure an accurate figure on the total loss through conk-rot. In actual practice the writer would use 20 feet as the upwal'd or downward extent of decay beyond the highest or lowest sporophore and 10 feet as the figure for swollen knots. In other words, in the case of a decayed tree with sporophores the trunk would be considered unmerchantable from a point 20 feet below the lowest sporophore to a point 20 feet above the highest sporophore, while for swollen knots the distance would be reduced to 10 feet below and above. These figures are easy to remember and have checked well with the writer's observations since this study was made; but for greater accuracy in any given locality it is well to study felled trees and watch long logs through the mili, so that these limits can be corrected to fit local conditions.

RED-BROWN BUT''-ROT.

Sporophores are, of course, the best indication of decay. The sporophores of red-brown butt-rot being annual are not common except in favorable seasons for their development, but can always be found now and then in a locality where the trees are affected. However, the best clue is fire scars. Noticeably fire-scarred trees are commonly infected with this decay. Of the 125 trees with fire scars that were studied, 41 , or 33 per cent, were infected with redbrown butt-rot. Healed fire scars can often be detected by a variation in the appearance of the bark over the wound or by swollen or churn butts. There are no swollen knots with this decay.

\section{BROWN TRUNK-ROT.}

Brown trunk-rot is rather hard to detect. Swollen knots are not formed. Sporophores are rare on living trees, but when they do occur they are very conspicuous and not readily overlooked. 
Furthermore, observation shows that they indicate extensive decay in the tree. Only one tree studied had sporophores of this rot, and the decay volume in cubic feet was 31 per cent and in board feet 74 per cent of the gross volume of the tree. But the total loss caused by this decay was trifling. (See Table 2.)

YELLOW-BROWN TOP-ROT.

Yellow-brown top-rot also is rather hard to judge. Swollen knots do not accompany the decay. Sporophores are not uncommon, particularly with the more extensive infections. In the trees studied, seven infections, which resulted in 42 per cent of the cubic-foot volume and 41 per cent of the board-foot volume of yellow-brown top-rot, had developed sporophores. However, the sporophores are commonly so high up in the trees that they are easily overlooked and, in fact, are often completely hidden by the branches. Broken or spike tops commonly indicate infection (see Table 7). The aggregate loss caused by this decay is small.

\section{INDICATIONS OF DECAY IN FELLED TIMBER.}

The estimate of the extent of defect in logs or felled timber is much easier than in standing trees. The red-brown butt-rot is revealed in the butt cut, and its upward extent can be more closely approximated. Knots can be tested carefully for signs of rot, and if the timber has been bucked the ends of the logs can be examined for typical decay or the discolorations caused by incipient decay. However, if the logs have been exposed to the weather for several months these discolorations fade and can not be seen.

It is not at all difficult to judge quite accurately the extent of conk-rot in felled Douglas fir by chopping into the knots to reveal the brown corky context of the abortive sporophore.

\section{EXTENT OF INCIPIENT DECAY.}

A knowledge of the vertical extent of incipient decay, which is the term used to designate the early stages of rot, beyond the typical decay or well-advanced rot is of practical value. In some infections the incipient decay may end with the typical decay and in other cases extend many feet beyond it. The horizontal or radial extent normally amounts to only a few inches. Incipient decay, which is usually indicated by a discoloration of infected wood, in some cases pronounced and in others so faint as to be practically invisible, is not always easy to detect. Affected wood in a casual examination seems to be firm and strong. Consequently, it is the rule rather than the exception in the lumber trade to include incipient decay with sound lumber.

Wood is weakened by incipient decay, the degree depending on the stage of the rot and also on the species of fungus at work. Tests (3) on Douglas fir with incipient decay of conk-rot showed that the wood was apparently not weakened, but pieces with incipient decay of red-brown butt-rot and brown trunk-rot, to which general type of decay yellow-brown top-rot also belongs, were much reduced in strength. Furthermore, if infected material is merely air dried, the hyphæ may remain dormant, ready to continue to decay the wood again if suitable conditions arise. Hence, wood with incipient decay 
should be excluded from all lumber to be used for purposes requiring strength and durability.

The incipient stage of conk-rot is often quite extensive. In one tree this stage of decay extended for 29.6 feet vertically in the heartwood beyond the typical decay, while in several infections this figure ranged from 10 to 20 feet. The average extent upward of incipient decay beyond the typical decay was 3.3 feet and the average extent downward was 4 feet. The significance of this difference will be touched upon later. The average extent both up and down was 3.5 feet, based on 145 measurements.

Red-brown butt-rot is less variable in respect to the extent of incipient decay. The greatest extent found was 8.4 feet, while the average based on 44 measurements was 1.95 feet. This average is based on measurements of upward extent only, since most of the infections began in the stump or extended into it and no downward measurements were possible.

Only meager data were available on brown trunk-rot. Based on 13 measurements the upward extent of the incipient decay was found to be 3.5 feet, while the downward extent was 3.6 feet. The combined average was 3.6 feet. The extreme extent was 8.5 feet above typical decay.

The incipient decay of yellow-brown top-rot had an average extent upward of 2.2 feet and downward of 3.8 feet, while the combined average was 3.1 feet, based on 58 measurements. In one tree incipient decay extended up beyond typical decay for a distance of 25.4 feet.

From the foregoing it can be seen that in all three of the rots in which it was possible to make a comparison between the upward and downward extent of incipient decay the downward extent exceeded the upward on the average, and the difference is most striking in yellow-brown top-rot, where most of the infections occur in the upper part of the bole. This difference is probably explained by the well-known fact that older trees are much more subject to decay than younger ones, and therefore it follows that older heartwood is more susceptible than younger. As the fungus progresses downward in the heartwood of a tree it encounters wood gradually increasing in age and easier to decay, while as it mores upward younger wood which offers more resistance is continually invaded, decreasing the extent of both typical and incipient decay. This tendency for decay to work more rapidly downward than upward is in keeping with other observations $(1$, p. 21).

The figures presented on the extent of incipient decay show that this is quite variable and indicate the need for careful inspection to eliminate this type of defect from timbers where durability and strength are a prerequisite.

\section{SUMMARY.}

The four principal decays in Douglas fir are conk-rot caused by the ring-scale fungus (Trametes pini), red-brown butt-rot caused by the velvet-top fungus (Polyporus schweinitzii), brown trunk-rot caused by the quinine fungus (Fomes laricis), and yellow-brown toprot caused by the rose-colored Fomes (Fomes roseus). Conk-rot and brown trunk-rot usually occur in the body of the trunk, red-brown butt-rot is commonly confined to the stump and first log, while yellow- 
brown top-rot usually occurs in the upper bole or top. Conk-rot causes by far the greatest volume of decay. The other three rots are of relatively minor importance, except that red-brown butt-rot predisposes an infected tree to windfall.

Douglas fir is subject to wounding throughout its life and particularly to injury by fire during its earlier years. On the whole, wounds in Douglas fir are mostly superficial, and this tree species heals rapidly after wounding. Scars callus very irregularly, and it is usually difficult or impossible to determine the exact dates when scars were made.

Mechanical injuries are of little importance in relation to the entrance of decay. Knots were responsible for nearly 90 per cent of the volume of all decay in the trees studied. Fire scars were the entrance point for 4 per cent, and the remaining 6 per cent came in through other scars. Fire is the only factor which is controllable, so there can be but little reduction in the extent of decay in future stands by a reduction in the scars caused by controllable mechanical injuries.

Recognition of the indications of decay in standing or felled timber is of the greatest importance from a practical standpoint, yet this is little understood. Branch fans, dead limbs, or burls do not indicate decay. Sporophores and swollen knots which develop prolifically indicate the presence of conk-rot. After a stand has been fire swept, burned-out hollows show where there were sporophores and swollen knots. It is also possible to approximate with some accuracy the volume of the decay. Conk-rot, on the average, extended approximately 20 feet in the trunk beyond the highest or lowest sporophore and 10 feet beyond the highest or lowest swollen knot. Sporophores of red-brown butt-rot are not common. However, the relative frequency of fire scars indicates somewhat the relative amount of this decay. Churn butts often denote old fire scars. Brown trunk-rot is rather difficult to detect in standing trees, but the loss caused by this decay is insignificant. This also applies to yellow-brown top-rot.

Figures on the different rots, giving the extent of incipient decay beyond typical decay, show that this is rather variable, thus requiring careful inspection to obviate the inclusion of wood with this type of defect in timbers selected for durability and strength.

\section{OUTLOOK.}

The work on which the preceding discussion is based is merely preliminary. More extensive studięs are needed to bring out new facts and develop still further those already brought out. This should aid materially in placing the estimating of Douglas-fir timber on a more exact basis.

The biggest problems remain unsolved. Our half-formulated ideas of control of decay in Douglas fir are based on observation without a sound backing of exact data. Furthermore, while it is a wellestablished fact that young stands or second growth are relativelv immune from decay, it is not yet determined at what age in the life of the stand this immunity ceases and the trees become subject to extensive decay. Establishing this age will enable us in the future 
to cut stands before there is any real loss and at the same time permit the trees to attain the maximum size.

Equally important is the periodic rate of increase in the loss through decay after the above age has been passed. Such information is of the highest value to organizations holding extensive stands of mature or overmature timber, enabling them to estimate the loss in their holdings and adapt plans accordingly. But these questions can only be answered by the study of all the trees felled and left standing on a wide range of plats in stands of different ages and conditions selected on logging operations throughout the Douglas-fir region of the Pacific Northwest. 


\section{LITERATURE CITED.}

(1) BOyCE, J. S.

1920. The dry-rot of incense cedar. U. S. Dept. Agr. Bul. 871,58 p., 3 fig., 3 pls., 11 tables. Literature cited, p. 57-58.

(2) Chapman, Ilerman Haupt.

1921. Forest mensuration. xxii, 553 p., 88 fig., 89 tables. New York.

(3) Colley, R. H.

1921. The effect of incipient decay on the mechanical properties of airplane timber. (Abstract.) In Phytopathology, v. 11, p. 45.

(4) Möller, A.

1904. Über die Notwendigkeit und Möglichkeit wirksamer Bekämpfung des Kiefernbaumschwammes Trametes Pini (Thore) Fries. In Ztschr. Forst. u. Jagdw., Jahrg. 36., p. 677-715, pl. 4-5.

(5) U. S. Dept. Agr., Forest Service.

1916. Instructions for the scaling and measurement of national forest timber. 94 p., 10 tables. Washington, D. C.

1920. Timber depletion, lumber prices, lumber exports, and concentration of timber ownership. 71 p., 22 fig., 26 tables. Washington, D. C.

(7) Weir, James R., and Hubert, Ernest E.

1918. A study of heart-rot in western hemlock. U. S. Dept. Agr. Bul. 722, 39 p., 13 fig. Bibliographical footnotes.

(8) 1919. A study of the rots of western white pine. U. S. Dept. Agr. Bul. 799, $24 \mathrm{p}$. Bibliographical footnotes. 


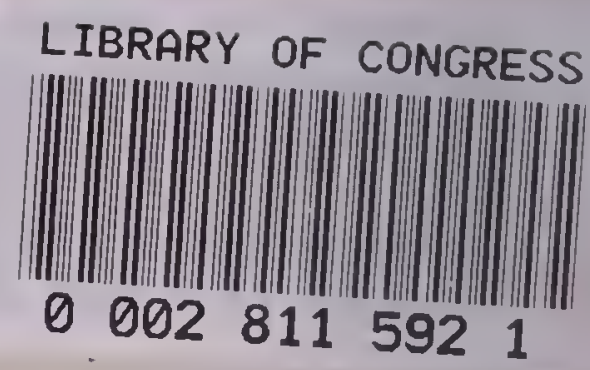

\section{ORGANIZATION OF THE UNITEI) STATES DEPARTMENT OF AGRICULTURE.}

Secretary of Agriculture.................. Henry C. Wallace.

Assistant Secretary.................... C. W. Pugsley.

Director of Scientific Work............... E. D. BALL.

Dircctor of Regulatory Work.................

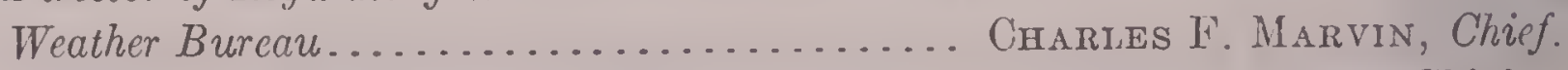

Bureau of Agricultural Economics........... Henry C. Taylor, Chief.

Bureau of Animil Industry............. JoHn R. Mohler, Chief.

Bureau of Plant Industry............... Wrlliam A. TAylor, Chief.

Forest Service....................... B. Greeley, Chief.

Bureau of Chemistry.................... Walter G. Campbell, Acting Chief..

Bureau of Soils...................... Milton Whit'ney, Chief.

Bureau of Entomology................. L. O. Howard, Chief.

Bureau of Biological Survey.............. E. W. NELSON, Chief.

Bureau of Public Roads.................. Thomas H. MacDonald, Chief.

Fixed Nitrogen Research Laboratory.......... F. G. CotTrELL, Director.

Division of Accounts and Disbursements....... A. ZAPPONE, Chief.

Division of Publications................ Edwin C. Powell, Acting Chief.

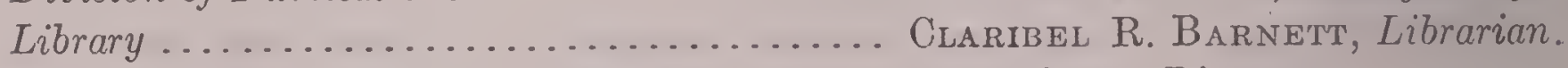

States Relations Scrvice................. A. True, Director.

Federal Horticultural Board................ C. L. Marda'T, Chairman.

Insecticide and Fungicide Board............ J. K. Haywood, Chairman.

Packers and Stockyards Administration........ Ghester Morrill, Assistant to the Grain Future Trading Act Administration.... Secretary.

office of the Solicitor...................... Wrlliams, Solicitor.

This bulletin is a contribution from

Bureau of Plant Industry................ Wildiam A. Taylor, Chief. Office of Investigations in Forest Pathology. Haven Metcalf, Pathologis $t$ in

ADDITIONAL COPIES

OF THIS PUBLICATION MAY BE PROCURED FROM 'THE SUPERINTENDENT OF DOCUMENTS GOVERNMENT PRINTING OFFICE

WASHINGTON, D. C.

AT

10 CENTS PER COPY

PURCIASER AGREES NOT TO RESELL OR DISTRIBUTE THIS COPY FOR PROFIT.-PUB. RES. 57, APPROVED MAY 11, 1922 